\title{
Syysrukiin perustaminen, hoito ja rikkaruohojen ekologia
}

\author{
Mikko Raatikainen ja Terttu Raatikainen \\ Jyväskylän yliopisto, Biologian laitos, 40100 Jyväskylä 10 ja \\ Maatalouden tutkimuskeskus, kasvinviljelylaitos 01300 Vantaa 30
}

\section{Establishing and management of winter rye and the ecology of weeds in rye fields}

\author{
Mikko RaAtikainen and Terttu RaAtikainen \\ University of Jyväskylä, Department of Biology, SF-40100 Jyväskylä 10, Finland, and \\ Agricultural Research Centre, Department of Plant Husbandry, SF-01300 Vantaa 30, Finland
}

\begin{abstract}
The survey was carried out on 325 winter-rye fields, chosen by random sampling method. The area of the fields was $0.7 \%$ of the total rye cultivation area in Finland.

The characteristics of the ryefields and the methods of establishing and managing the rye were investigated in the survey.

176 vascular plant species were found on the ryefields. The number of species was highest in eastern Finland. The frequency percentage of all species was determined. The average weed number on the fields was $303 / \mathrm{m}^{2}$. The density was lowest in southwestern Finland. The number of plants or shoots $/ \mathrm{m}^{2}$ was determined. Winter annuals Viola arvensis, Stellaria media, Matricaria spp., Myosotis arvensis and Lapsana communis, summer annuals Galeopsis spp., Chenopodium album and Erysimum cheiranthoides, and perennials Agrostis spp., Agropyron repens, Poa pratensis and Ranunculus repens had the highest density.

The area of the farm, the age of the cultivated field, soil type, the moisture conditions of soil, the number of combine harvestings, the number of herbicidal treatments, previous crop, sowing time, seed dressing, the phase of the growing season, the cover percentage of cereal and the cultivation area influenced either directly the density of the weeds or proved density indicators. The rye cultivation area was divided into two sections on the basis of weeds.
\end{abstract}

\section{Johdanto}

Tämä tutkimus on toinen osa Maatalouden tutkimuskeskuksen kasvinviljelyosaston toimesta v. 1969 aloitetusta syysviljojen rikkakasvitutkimuksesta. Ensimmäisessä osassa (M. RAATIKAINEN et al. 1979) tarkasteltiin syysviljojen rikkaruoholajistoa, lajien yleisyyttä ja tiheyttä kesäkuussa kemiallisen torjuntakauden jälkeen. Tässä tarkastellaàn ruispeltojen ominaisuuksia, 
rukiin perustamista, hoitoa sekä rukiin rikkaruoholajien ekologiaa ja rikkaruohoisuuteen vaikuttaneita tekijöitä.

Syysrukiin perustamis- ja hoito-ohjeita on annettu lukuisissa oppaissa ja käsikirjoissa (mm. Sunila et al. 1915, Grotenfelt 1921-1922, SAuli 1929, Poijärvi ja Wecksell 1943, Simonen 1944, Majaniemi 1960, 1962, Köppä 1975, 1976, Mukula et al. 1976). Ohjeet perustuivat aluksi etenkin viljelijöiden kokemukseen, mutta myöhemmin lähes kokonaan tutkimustuloksiin. Rukiin viljely- ja hoitotavat poikkeavat kuitenkin ohjeista, ja käytössä olevia tapoja on selvitetty vain vähän. Grotenfelt (1899) ja SoIninen (1975) kuvaavat kuitenkin jonkin verran 1700 - ja 1800 -lukujen viljely- ja hoitotapoja. Myöhemmiltä ajoilta on hajanaisia tietoja useissa eri artikkeleissa (mm. Grotenfelt 1921-1922, Valle 1962, Vuorela 1975, Mukula et al. 1976).

\section{Tutkimusalueet ja menetelmät}

Tutkimuksen suoritustapa on selostettu ensimmäisessä osatutkimuksessa (M. RaAtikainen et al. 1979). Kenttätutkimus tehtiin haastattelemalla (huhti-kesäkuu 1972-1974) ja havainnoimalla (1.-18. VI. 1972-1974). Kahdeksallatoista tutkimusalueella oli yhteensä 325 ruislohkoa, joista 303:Ita oli täydelliset tiedot kaikista selittäjistä. Ruislohkojen jakaantuminen eri alueille ilmenee taulukosta 1 . Tutkittu syysruisala oli 451 ha, ja se oli $0.7 \%$ tutkimuskauden keskimääräisestä vuosittaisesta ruisalasta 61500 ha:sta. VäliSuomen alueeseen luetaan alueet 5, 6, 11, 12, 17 ja 18 . Muut alueet kuuluvat Lounais-Suomen alueeseen (ks. M. RAATIKAINEN et al. 1979).

Matemaattisina menetelminä käytettiin pienimmän neliösummon menetelmää (HARVEy 1966) ja regressioanalyysiä (DRAPER ja SMith 1966). Tilastollinen merkitsevyys ilmaistaan seuraavasti:

$$
{ }^{* * *} \mathrm{P}<0.001,{ }^{* *} \mathrm{P}<0.01 \text { ja }{ }^{*} \mathrm{P}<0.05 .
$$

Kasvimaantieteellistä aluejakoa tehtäessä käytettiin SøRENSENin (1948) yhtäläisyysverrannetta seuraavasti sovellettuna:

$$
\begin{aligned}
& \mathrm{QS}=100 \frac{\Sigma 2 \mathrm{c}}{\Sigma(\mathrm{a}+\mathrm{b})}, \text { jossa } \\
& \mathrm{a}=\text { lajin yksilömäärä alueen } 1 \text { näytealoilla } \\
& \mathrm{b}=\text { saman lajin yksilömäärä alueen } 2 \text { näytealoilla } \\
& \mathrm{c}=\text { pienempi edellä mainituista yksilömääristä }
\end{aligned}
$$

Aluejaon tekoon otettiin mukaan 102 yleisintä taksonia 176 mahdollisesta, koska kaikkia taksoneita ei säästäväisyyssyistä voitu ottaa tietokonekäsittelyyn. 
Taulukko 1. Syysviljojen tutkimusalueet ja lohkomäärä sekä ruislohkojen osuus niistä. Table 1. Winter cereal localities, the number of all the fields and the number of rye fields investigated.

\begin{tabular}{|c|c|c|}
\hline Alueen numero ja nimi & \multirow{2}{*}{$\begin{array}{l}\text { Tutkittujen syysvilja- } \\
\text { lohkojen lukumäärä } \\
\text { Number of investigated } \\
\text { winter cereal fields }\end{array}$} & \multirow{2}{*}{$\begin{array}{l}\text { Tutkittujen syysruis- } \\
\text { lohkojen lukumäärä } \\
\text { Number of investigatea } \\
\text { winter rye fields }\end{array}$} \\
\hline No. Locality & & \\
\hline 1 Perniö ................... & 30 & 6 \\
\hline 2 Lapinjärvi ................................... & 30 & 7 \\
\hline 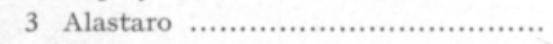 & 30 & 15 \\
\hline 4 Luvia-Nakkila ......................... & 27 & 20 \\
\hline 5 Hartola-Joutsa ......................... & 32 & 32 \\
\hline 6 Siilinjärvi-Lapinlahti ................... & 28 & 27 \\
\hline 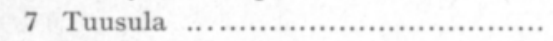 & 30 & 9 \\
\hline 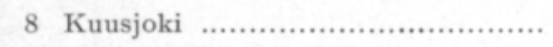 & 30 & 4 \\
\hline 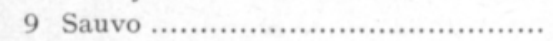 & 29 & 10 \\
\hline 10 Juupajoki-Orivesi ...................... & 30 & 10 \\
\hline 11 Parikkala-Saari ......................... & 30 & 30 \\
\hline 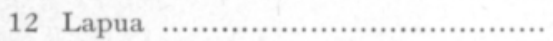 & 27 & 27 \\
\hline 13 Kirkkonummi ............................. & 31 & 18 \\
\hline 14 Mellilä ....................................... & 32 & 28 \\
\hline 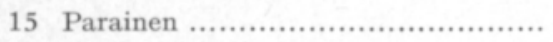 & 31 & 4 \\
\hline 16 Kalvola-Hattula ....................... & 33 & 21 \\
\hline 17 Saarijärvi-Äänekoski ..................... & 30 & 30 \\
\hline 18 Oulainen-Haapavesi-Pulkkila ...... & 30 & 27 \\
\hline 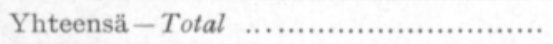 & 540 & 325 \\
\hline
\end{tabular}

\section{Tulokset ja tarkastelu}

\section{1. Ruista viljelevän tilan ja ruislohkon ominaisuudet}

3. 1. 1. Tilan peltoala

Ruista viljelleiden tilojen keskikoko oli Lounais-Suomen alueella suurempi kuin Väli-Suomen alueella (taulukko 2), kuten kaikkien tilojen keskikokokin peltoalan perusteella. Lounais-Suomen tilojen keskipeltoalahan oli saaristoa lukuun ottamatta yleensä yli 9 ha, Väli-Suomen 6-9 ha, Itä- ja Pohjois-Suomen alle 6 ha. Rukiin viljely oli Suomessa keskittynyt selvästi suurille ja keskikokoisille tiloille.

\section{1. 2. Lohkon ikä peltona}

Pellon raivauksen viljelijät muistivat yleensä melko tarkasti noin puolen vuosisadan taakse. Tätä vanhempien peltojen raivausajat tiedettiin summittaisesti noin sataan vuoteen saakka, mutta vanhemmista raivausajankohdista ei yleensä ollut enää tietoa.

Rukiin viljely jakaantui melko tasaisesti eri-ikäisille pelloille (taulukko 2). Tuloksista näkyy uudisraivaustoiminta, joka laajentui voimakkaasti 1900luvulla ja oli laajimmillaan 1930-luvun alussa sekä uudelleen sotien jälkeen v. 1950. Väli-Suomessa ruista viljeltiin keskimäärin nuoremmilla pelloilla kuin Lounais-Suomessa, koska Väli-Suomen pellot olivat yleensäkin nuorempia. 
Uudisraivaustoimintahan siirtyi tällä vuosisadalla vähitellen yhä pohjoisemmaksi; siellä raivauskelpoista peltoalaa oli eniten (РёLıкKö 1960).

\section{1. 3. Lohkon pinta-ala}

Koska ruislohko määriteltiin sellaiseksi ruispellon osaksi, jossa maalaji ja esikasvi olivat samoja, oli lohko muutamassa tapauksessa pienempi kuin maisemassa näkyvä ruispelto. Keskikooltaan nämä eri tavoin määrtiellyt ruispellot olivat kuitenkin lähes samankokoisia.

Ruislohkojen keskikoko suureni lounasta ja länttä kohden (taulukko 2). Lounais-Suomen alueella se oli 1.8 ha, Väli-Suomen alueella 0.9 ha ja koko maan keskiarvo oli 1.3 ha.

\section{1. 4. Lohkon etäisyys talouskeskuksesta}

Ruislohkon etäisyys talouskeskuksesta mitattiin lyhintä viljelystietä pitkin. Yli puolet tutkituista lohkoista oli alle $400 \mathrm{~m}: n$ etäisyydellä (taulukko 2). Lounais-Suomen alueella lohkot olivat keskimäärin vähän kauempana kuin Väli-Suomen alueella, jossa tärkein leipävilja ruis sijoitettiin tavallisesti talouskeskuksen ympärillä oleville intensiivisimmin hoidetuille pelloille. Tästä oli seurauksena, että ruispellot olivat samalla tilan vanhimmilla, ravinteisimmilla ja rikkaruohoisimmilla pelloilla.

\section{1. 5. Maalaji}

Järvi-Suomessa ruispellot sijaitsivat tavallisesti moreenimailla tai eloperäisillä mailla ja Etelä- sekä Lounais-Suomessa savimailla. Täten kaikista ruispelloista noin puolet oli karkeilla kivennäismailla, kolmannes savimailla ja loput eloperäisillä mailla (taulukko 2). Ruista on suositeltu viljeltäväksi etenkin hiekkamailla, joilla se poutaa verraten hyvin kestävänä menestyy muita viljalajeja paremmin (esim. SAUli 1929, VAlle 1962). Eloperäisillä mailla ruis usein harvenee talvituhosienien ja roudan takia (esim. SAULI 1929, VAlle 1962, Heinonen 1975).

\section{1. 6. Maaperän kosteus}

Ruista viljeltiin etenkin keskinkertaisen kosteilla ja poutivilla mailla (taulukko 2). Tämä on myös suositusten mukainen tapa (esim. SAULI 1929, VALLE 1962), sillä ruis on kevätkuivuutta paremmin kestävä kuin kevätviljat. Viljelyä saattaisi siirtää nykyistä enemmänkin poutiville maille, joilla ruis näyttää olevan kevätviljoja viljelyvarmempi kasvi (vrt. Mukula et al. 1976).

\section{1. 7. Ojitus}

Rukiin viljely keskittyi avo-ojitetuille tai ojattomille pelloille, jollaisia oli varsinkin Väli-Suomen alueen itä- ja keskiosissa (taulukko 2). Lounais-Suomen alueellakin ruista viljeltiin usein tällaisilla paikoilla, vaikka kyseisellä alueella oli monissa pitäjissä suurin osa pelloista salaojitettuja (AnoN. 1974). Ojittamattomat maat olivat usein poutivia, eivätkä ne olleet usein ojituksen tarpeessakaan. Ojattomilla ja avo-ojitetuilla paikoilla oli kuitenkin toisinaan kiviä, jotka vaikeuttivat tehokasta viljelyä ja edistivät rikkaruohojen kasvua saroilla. 
Taulukko 2. Tutkimustilojen ja ruislohkojen ominaisuuksia sekä rukiin viljelytekniikkaa selvittäviä tietoja. Aluejaon rajat selostettu luvussa 2.

Table 2. Data on the characteristics of farms and rye fields investigated and on the methods of cultivating rye.

\begin{tabular}{cccccccc}
\hline Lounais- & Väli- & Koko & Lounais- & Väli- & Koko \\
& Suomi & Suomi & maa & Suomi & Suomi & maa \\
& Southwest & Middle & Whole & Southwest & Middle & Whole \\
Finland & Finland & country & Finland & Finland & contry \\
$\%$ & $\%$ & $\%$ & $\%$ & $\%$ & $\%$ \\
\hline
\end{tabular}

Tilan peltoala, ha

Farm arable area, ha

$\begin{array}{rrrr}1-5 & 5 & 4 & 5 \\ 6-10 & 11 & 28 & 20 \\ 11-25 & 39 & 52 & 45 \\ 26-50 & 32 & 12 & 22 \\ 51- & 13 & 4 & 8\end{array}$

Lohkon ikä peltona, vuotta

Age of cultivated field, years

$$
\begin{gathered}
1-29 \\
30-59 \\
60-89 \\
90-119 \\
120-
\end{gathered}
$$

Lohkon pinta-ala, ha Area of field, ha

$$
\begin{array}{r}
-0.5 \\
0.6-1.0 \\
1.1-2.0 \\
2.1-3.0 \\
3.1-4.0 \\
4.1-
\end{array}
$$

Lohkon etäisyys talouskeskuksesta, m Distance of field from farmstead, $m$

$$
\begin{array}{r}
-\quad 99 \\
100-199 \\
200-399 \\
400-799 \\
800-1599 \\
1600-3199 \\
3200-
\end{array}
$$

Maalaji - Soil type

Karkeat kivennäismaat ja hiesut Coarse mineral soils and silts

Savimaa - Clay soils 17

Eloperåiset maat Organic soils

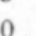

Maaperän kosteus -

Moisture conditions

of soil

Poutiva - Dry

Keskinkertainen -

Medium

Veden vaivaama $-W e t$

21

9

14

72

84

79

7

7

Ojitus - Type of

drainage

Avo-ojitus -

Open drainage

Salaojitus -

Underdrainage

26

55

42

Ojaton - Undrained

58

14

34

$16 \quad 31$

24

Leikkuupuintien määrä/

10 vuotta

Combine harvesting

during 10 years

$$
\begin{aligned}
& 0- \\
& 1-2 \\
& 3-4 \\
& 5-6 \\
& 7-8 \\
& 9-
\end{aligned}
$$

$\begin{array}{rrr}4 & 34 \\ 11 & 24 \\ 13 & 22 \\ 22 & 11 \\ 28 & & 5 \\ 22 & & 4\end{array}$

$\begin{array}{rr}34 & 20 \\ 24 & 19 \\ 22 & 18 \\ 11 & 16 \\ 5 & 15 \\ 4 & 12\end{array}$

Rikkaruohoruiskutusten määrä/10 vuotta

Herbicidal treatments

during 10 years

$$
\begin{aligned}
& 0 \\
& 1-2 \\
& 3-4 \\
& 5-6 \\
& 7-8 \\
& 9-
\end{aligned}
$$

14
12
16
23
23
12

$\begin{array}{rr}45 & 31 \\ 23 & 18 \\ 16 & 16 \\ 10 & 16 \\ 5 & 13 \\ 1 & 6\end{array}$

Esikasvi -

Previous crop

Ohra - Barley

Kaura - Oats

17
8

14 
Kevätvehnä -

Spring wheat

Kevätvilja -

Spring cereal

Ruis - Rye

Syysvehnä -

Winter wheat

Syysvilja -

Winter cereal

Rypsi - Turnip rape

Nurmi - Ley

Yksivuotineil rivi-

viljelykasvi

Annual row crop

Kesanto - Fallow

Uudisraivio - Clearing

Tuntematon -

Unknown

Viljelykasvi kaksi

vuotta sitten

Crop two years ago

Kevätvilja -

Spring cereal

Syysvilja -

Winter cereal

Vilja - Cereal

Rypsi - Turnip rape

Nurmi - Ley

Yksivuotinen rivi-

viljelykasvi

Annual row crop

Kesanto - Fallow

Tuntematon -

Unknown

Viljelykasvi kolme

vuotta sitten

Crop three years ago

Kevätvilja -

Spring cereal

Syysvilja -

Winter cereal

Vilja - Cereal

Rypsi - Turnip rape

Nurmi - Ley

Yksivuotinen rivi-

viljelyskasvi

Annual row crop

Kesanto - Fallow

Tuntematon -

Unknown
8

26

2

1

3

15
4

17

1

0

2

38
Viljelykasvi neljä

vuotta sitten

Crop four years ago

Kevätvilja -

Spring cereal

41

36

39

Syysvilja -

Winter cereal

Vilja - Cereal

Rypsi - Turnip rape

Nurmi - Ley

Yksivuotinen rivi-

viljelykasvi

Annual row crop

Kesanto - Fallow

3

1

Tuntematon -

Unknown

1

Karjanlannan määrä, t/ha

Farmyard manure,

tons/ha

$$
\begin{aligned}
& 0- \\
& 1-20 \\
& 21-40 \\
& 41-60 \\
& 61-
\end{aligned}
$$

$\begin{array}{rr}59 & 70 \\ 19 & 14 \\ 13 & 10 \\ 2 & 2 \\ 7 & 4\end{array}$

42

22

18

2

2

24

70

8

1

48

19

33

13

3

1

30

2

3

0
31

10

2

1

48
Typpimäärä väki-

lannoitteena syksyllä, kg/ha

Nitrogen fertilization

in autumn, $\mathrm{kg} / \mathrm{ha}$

$$
\begin{array}{r}
0- \\
1-50 \\
51-75 \\
76-
\end{array}
$$

4

Fosforimäärä väki-

lannoitteena syksyllä, kg/ha

Phosphorus fertilization

in autumn $\mathrm{kg} / \mathrm{ha}$

$$
\begin{aligned}
& 0- \\
& 1-30 \\
& 31-60 \\
& 61-
\end{aligned}
$$

Kaliummäärä väki-

lannoitteena syksyllä, kg/ha

Potassium fertilization

in autumn, kg/ha

$$
\begin{gathered}
0- \\
1-50 \\
51-75 \\
76-
\end{gathered}
$$

5
35
46
14

Jatkuu - Continued 
Ruislajike -

Rye cultivar

Ensi

Toivo

Pekka

Voima

Maatiaiset

Vjatka

Muut - Others

Kylvösiemenen peittaus

Seed dressing

$\mathrm{Ei}-\mathrm{No}$

Kyllä - Yes

9
16. -20 . V

21. -25 . V

26. -30 . V

$-31 . \mathrm{V}$

20

18

18

7

3

8

Kylvősiemenmäärä, kg/ha

Seed rate, $\mathrm{kg} / \mathrm{ha}$

$$
\begin{array}{r}
-150 \\
160-180 \\
190-210 \\
220-
\end{array}
$$

Kylvöaika

Sowing time

2. -13 . VIII
14. -23 . VIII

24. VIII-2. IX

3. -12 . IX

13. -25 . IX

Typpilannoitus talvella

Nitrogen fertilization

in winter

$\mathrm{Ei}-\mathrm{No}$

Kyllä - Yes

99

1

Typpilannoitus

keväällä, kg/ha

Nitrogen fertilization

in spring, kg/ha

$$
\begin{array}{r}
0- \\
1-50 \\
51-75 \\
76-
\end{array}
$$

Rikkaruohoruiskutus

Herbicidal treatment

$\mathrm{Ei}-\mathrm{No}$

Kyllä - Yes

Rikkaruohojen ruiskutusaika

Time of herbicidal

treatment

$$
-10 . \mathrm{V}
$$

11. -15 . V

aine

Herbicide used

Mekoproppi -

Mecoprop mecoprop and

dichlorprop

2,4-D-seokset

seokset and TBA seokset

and ioxynil määrä, $1 /$ ha

treatments

Rikkaruohontorjunta-

MCPA - MCPA

MCPA-, mekoproppi-

ja diklorproppiseokset Mixtures with MCPA,

Mixtures with 2,4-D

Dikamba- ja 2,3,6-TBA

Mixtures with dicamba

Dinosebi- ja ioksiniili-

Mixtures with dinoseb

Rikkaruohoruiskutuksessa käytetty vesiAmount of water, 1/ha, used in herbicidal

$$
99
$$$$
1
$$

$175-224$

$225-274$

$275-324$

$325-400$

Korrenvahvisteen

käyttō v. 1973-1974

Use of growth regulators in 1973-1974

$\mathrm{Ei}-\mathrm{No}$

Kyllä - Yes

98 85

Ruis nurmikasvien suojaviljana Rye as nursecrop for leyplants

$\mathrm{Ei}-\mathrm{No}$ Kyllä - Yes

$\begin{array}{rrr}61 & 60 & 61 \\ 21 & 33 & 23 \\ 10 & 7 & 9 \\ 8 & 0 & 7\end{array}$


3. 1. 8. Leikkuupuintien määrä ennen rukiin viljelyä

Leikkuupuintikerrat ruislohkolla 10 viime vuoden aikana ennen rukiin viljelyä saatiin selville 318 lohkolta. Väli-Suomen alueella, jossa suurin osa pelloista oli nurmina, ruislohkoista vain $66 \%$ :lla oli käytetty kyseisenä aikana leikkuupuntia, ja niilläkin lohkoilla, joilla sitä oli käytetty, käyttökertoja oli keskimäärin 3.7 (taulukko 2). Lounais-Suomen alueella $96 \%$ :lla ruislohkoista oli käytetty leikkuupuimuria 10 viime vuoden aikana, ja näillä lohkoilla sitä oli käytetty keskimäärin 6.1 kertaa. Koko maan aineisto osoittaa, että ruista viljeltiin tavallisimmin nurmivaltaisessa viljelykierrossa. Tällaisilla tiloilla leikkuupuinti korjuumenetelmänä oli harvinainen. Toinen viljelykiertotyyppi oli viljavaltainen, ja näillä tiloilla leikkuupuintia oli käytetty jo pitkän aikaa. Edellinen tyyppi oli yleinen Väli-Suomen ja jälkimmäin Lounais-Suomen alueella. Leikkuupuinnin käyttö aiheutti rikkaruohottumista ja se vuorostaan herbisidien käytön.

\section{1. 9. Rikkaruohoruiskutusten määrä ennen rukiin viljelyä}

Herbisidien käyttökerrat ruislohkolla 10 viime vuoden aikana ennen rukiin viljelyä saatiin melko luotettavasti selville 318 lohkolta. Tulokset osoittavat, että herbisidejä oli käytetty harvemmin kuin leikkuupuintia (taulukko 2). Väli-Suomen alueella käyttökertojen määrä ruiskutetuilla lohkoilla oli keskimäärin 3.3 ja Lounais-Suomen alueella 5.6. Pitkäaikaisesta käytöstä on ollut seurauksena, että syysviljojen rikkaruoholajien yksilötiheyksien suhteet ovat ehtineet muuttua alkuperäisestä varsinkin Lounais-Suomen alueella (MUkULA et al. 1969), jossa herbisidejä oli ehditty käyttää $86 \%$ :lla tutkimuskautena rukiilla olleista lohkoista 10 viime vuoden aikana. Herbisidien käyttö on kuitenkin ollut Suomessa verraten lyhytaikaista, sillä se laajeni huomattavasti vasta 1960-luvun alussa ja oli pitkän aikaa yleistä vain Lounais-Suomen alueella (Mukula ja Ruuttunen 1969).

\section{1. 10. Kasvijärjestys}

Esikasvi saatiin selville 321 lohkolta, joista 148 oli Lounais-Suomen ja 173 Väli-Suomen alueella.

Tavallisimmin ruis kylvettiin nurmen jälkeen (taulukko 2), ja Väli-Suomen alueella peräti $56 \%$ rukiista oli nurmen jälkeen kierrossa. Kevätviljat, varsinkin aikainen ohra, olivat myös suosittuja esikasveja. Seuraavilla sijoilla olivat syysviljat ja kesanto varsinkin Lounais-Suomen alueella.

Ruis oli aikoinaan suosittu uudisviljelysten kasvi. Kun uudisraivaustoiminta lähes tyystin loppui ja pellon käytön rajoittamisesta annettiin v. 1969 laki ja asetus, ei ruista ollut 1970-luvun alussa kuin $1 \%$ :lla tutkituista lohkoista uudisviljelykasvina ja nekin olivat kaikki Väli-Suomen alueella. Tämän vuosisadan alussa ruista viljeltiin tavallisimmin täyskesannon jälkeen (SAUli 1929, 1943). Seurauksena oli, että ruis- ja kesantoala olivat vuosisadan alussa lähes samansuuruiset. Tämä viljelytapa kävi kuitenkin taloudellisesti heikosti kannattavaksi. Kun samanaikaisesti nurmien peltoviljely yleistyi, siirryttiin käyttämään puolikesantoa ja etenkin nurmea esikasvina. Karjatto- 
maan talouteen ja viljavaltaiseen kasvijärjestykseen siirryttäessä alettiin ruista viime vuosikymmeninä yhä useammin kylvää joko aikaisten kevätviljalajikkeiden tai syysvehnän jälkeen; näin ehkäistiin tyvitautien runsastumista vehnävaltaisessa viljelyssä. Ruista rukiin jälkeen on viljelty etenkin LounaisSuomessa, jossa vähälumisilla alueilla talvituhosienten runsastumisvaara on pienin. Viime aikoina Maatalouskeskusten Liitto on suositellut rukiin viljelyä kesannon, nurmen, syysrypsin, herneen ja aikaisen ohran jälkeen (ANov. 1975).

Väli-Suomen alueella, jossa käytettiin tavallisimmin nurmivaltaista kasvijärjestystä, oli ruislohkojen yleisin viljelykasvi myös $2-4$ vuotta ennen rukiin viljelyä monivuotinen nurmi (taulukko 2). Lounaís-Suomen alueella, jossa usein käytetään viljavaltaisia kasvijärjestyksiä, oli ruislohkojen yleisin viljelykasvi myös $2-4$ vuotta ennen rukiin viljelyä kevätvilja. Toisella sijalla oli nurmi ja sitten syysvilja.

Koska nurmikasvien ja viljojen viljely ruislohkolla ennen rukiin viljelyä ovat vaihtoehtoja ja toisensa poissulkevia, käytetään tässä julkaisussa rikkakasvilajien yksilötiheyden selittäjänä esikasvin lisäksi nurmien lukumäärää kolmena ruisvaihetta edeltävänä vuonna.

\section{2. Rukiin perustaminen}

\section{2. 1. Peruslannoitus}

Peruslannoituksessa pyritään antamaan typpi lähinnä syksyn tarvetta varten ja fosfori sekä kali koko satoa varten. Suositusten mukaan karjanlantaa ei tulisi antaa rukiille ainakaan paljon lukuunottamatta täyskesantoon perustettavaa ruista (esim. Sauli 1943, Valle 1962). Tulosten (taulukko 2) mukaan karjanlantaa annettiin kuitenkin karjatalousvaltaisella Väli-Suomen vyöhykkeellä $41 \%$ :lle ja viljavaltaisella Lounais-Suomen alueellakin $19 \%$ :lle ruislohkoista. Karjanlantaa annettiin paikoitellen selvästi yli suositellun määrän, joka on 20-30 t/ha (ANoN. 1975).

Väkilannoitteita käytettiin ruispeltojen peruslannoitukseen yleisemmin kuin karjanlantaa, sillä Lounais-Suomen alueella niitä annettiin $97 \%$ :lle, Väli-Suomen alueella $88 \%$ :lle ja koko maassa $92 \%$ :lle ruislohkoista (taulukko 2). Useissa tapauksissa vähän karjanlantaa saaneille lohkoille annettiin lisäksi väkilannoitteita. Niiden käytössä oli siirrytty lähes yksinomaan seoslannoitteisiin. Typen käyttö peruslannoitukseen oli lähes ohjeiden mukaista. Typpeä käytettiin Lounais-Suomen savimailla viljan jälkeisillä ruispelloilla enemmän kuin Väli-Suomen moreeni-, hieta- ja eloperäisillä mailla nurmen jälkeisillä ruispelloilla (vrt. Pessi 1970). Viljelytapojen muuttuessa suositeltiin tutkimuskautena sänkimaahan perustettuun rukiiseen vähintään $60-90 \mathrm{~kg}: \mathrm{n}$ typpilannoitusta (KARES 1973). Näin suuria määriä kuitenkin vain harvat käyttivät, ja $100 \mathrm{~kg}$ typpeä oli Luostarisen ja LAASOSEN (1973) mukaan kannattavan lannoituksen yläraja kaikkina vuosina. Fosforin ja kalin käyttö oli runsaampaa Lounais-Suomen kuin Väli-Suomen alueella. Fosforilannoitus oli yleensä vähintään riittävä, mutta kalimäärät jäivät varsinkin Väli-Suomen alueella suositeltuja määriä pienemmiksi (vrt. PEssı 1970). 
Taulukko 3. Syysrukiissa kasvavien rikkaruohojen yleisyys ja yksilö- tai versomäärä $/ \mathrm{m}^{2}$ kaikilla lohkoilla alueittain ja koko maassa. $-=$ ei lôydetty.

Table 3. The frequency and number of weed plants or shoots $/ m^{2}$ in winter rye on all the fields in different regions and in the whole country.

\begin{tabular}{llllll}
\hline \multicolumn{2}{l}{ Yleisyysprosentti } & & \multicolumn{2}{l}{$\mathrm{Kpl} / \mathrm{m}^{2}$ kaikilla lohkoilla } \\
Lounais- Väli- & Koko & Lounais- Väli- Koko \\
Suomi & Suomi & Suomi & Suomi Suomi Suomi \\
Frequency-\% & & No. $/ m^{2}$ on all the fields \\
South- & Middle & Whole & South- Middle Whole \\
west & Finland & Finland & west Finland Finland \\
& Finland & & & Finland \\
\hline
\end{tabular}

Achillea millefolium

A. ptarmica

Aegopodium podagraria

Agropyron repens

Agrostis spp.

Alchemilla vulgaris cs:ll.

Alopecurus aequalis

A. geniculatus

A. pratensis

Alopecurus spp.

Anemone nemorosa

Angelica silvestris

Anthemis spp.

Anthoxanthum odoratum

Anthriscus silvestris

Arabidopsis thaliana

Arenaria serpyllifolia

Artemisia vulgaris

Atriplex patula

Atriplex spp.

Barbarea vulgaris

Betula spp.

Bidens tripartita

Brassica campestris

Brassica spp.

Calamagrostis spp.

Callitriche sp.

Caltha palustris

Campanula glomerata

C. patula

C. rotundifolia

Campanula spp.

Capsella bursa pastoris

Cardaminopsis suecica

Carex nigra

Carex spp.

Carum carvi

Centaurea cyanus

Cerastium arvense

C. caespitosum

Chamaenerion angustifolium

Chenopodium album s. lat.

14

5

1

30

28

1

3

3

1

3

2

$-$

3

-

3

$$
3
$$$$
1
$$$$
1
$$$$
3
$$

1

3

9

1

1

3

1

-

1

$-$

$-$

1

$-$

36

1

$-$

1

1

13

$-$

28

3

88
46

26

3

47

54

3

$-$

3

2

$-$

$-$

2$$
-
$$$$
5
$$$$
5
$$$$
6
$$$$
-
$$$$
1
$$$$
\text { - }
$$$$
1
$$

2

1

1

1

1

$-$

1$$
-
$$$$
1
$$$$
1
$$$$
1
$$$$
24
$$$$
\begin{array}{r}
24 \\
1
\end{array}
$$$$
1
$$$$
\begin{aligned}
& 8 \\
& 1
\end{aligned}
$$$$
16
$$$$
2
$$$$
54
$$$$
23
$$

86

16

2

39

42

2

2

3

2

1

1

1

1$$
1
$$$$
2
$$$$
2
$$$$
5
$$$$
\begin{aligned}
& 5 \\
& 0
\end{aligned}
$$$$
\begin{aligned}
& 0 \\
& 1
\end{aligned}
$$

1
2

2
1

2

4

4
1

1

1

2

1

$$
\begin{aligned}
& 0 \\
& 0
\end{aligned}
$$$$
1
$$$$
\begin{aligned}
& 1 \\
& 0
\end{aligned}
$$$$
+
$$$$
29
$$$$
1
$$$$
\begin{aligned}
& 0 \\
& 5
\end{aligned}
$$$$
\begin{aligned}
& 5 \\
& 1
\end{aligned}
$$$$
14
$$$$
1
$$

42

14

86

0.8

0.2

0.0

6.2

2.9

0.2

0.4

0.1

0.0

0.0

$-$

$-$

0.0

$-$

$-$

0.4

$-$

0.0

0.4

0.1

0.1

1.2

0.0

0.1

0.0

$-$

$-$

$-$

$-$

$-$

0.0

$-$

1.8

0.0

$-$

0.0

$-$

0.7

$-$

1.3

0.1

29.0
5.8

3.5

2.1

0.1

1.3

18.6

12.9

26.4

15.6

0.1

0.1

$-$

0.3

0.2

0.2

0.2

0.1

0.0

$-$

0.0

0.0

0.0

0.0

0.1

0.0

0.1

1.2

$-$

0.0

0.2

0.1

0.1

0.5

0.0

0.0

0.0

$\begin{array}{cc}- & - \\ 0.0 & 0.0\end{array}$

-

$-$

0.1

0.0

0.0

0.0

2.4

0.0

2.8

0.0

-

013

0.8

0.0

3.0

0.7

27.0

Continued 
Yleisyysprosentti

Lounais- Väli-

Suomi Suomi

Frequency-\%

Sout- Middle

west Finland

Finland
$\mathrm{Kpl} / \mathrm{m}^{2}$ kaikilla lohkoilla

Koko Lounais- Väli- Koko

Suomi Suomi Suomi Suomi $\mathrm{No} / \mathrm{m} \mathrm{m}^{2}$ on all the fields

Whole South- Middle Whole

Finland west Finland Finland Finland
Chenopodium polyspermum

Chrysanthemum leucanthemum

s. lat.

C. vulgare

Cirsium arvense

C. heterophyllum

C. palustre

Convolvulus arvensis

Comarum palustre

Corydalis solida

Crepis tectorum

Dactylis glomerata

Daucus carota

Deschampsia caespitosa

D. flexuosa

Dryopteris spinulosa

Epilobium montanum

E. palustre

Epilobium spp.

Equisetum arvense

E. fluviatile

E. palustre

E. silvaticum

Erophila verna

Erysimum cheiranthoides

Euphrasia brevipila

Festuca ovina

Festuca rubra

F. pratensis

Festuca spp.

Filipendula ulmaria

Fragaria vesca

Fumaria officinalis

Gagea minima

Galeopsis bifida

G. ladanum

G. speciosa

Galeopsis spp.

Galium palustre

G. uliginosum

G. vaillantii

Galium spp.

Geum rivale

Glechoma hederacea

Gnaphalium uliginosum

Heracleum sibiricum
2

1

$-$

13

$-$

$-$

$-$

$-$

1

$-$

$-$

1

2

$-$

$\overline{1}$

$-$

$-$

28

$-$

2

7

2

66

$-$

1

3

$-$

$-$

$-$

13

1

8

1

16

74

$-$

1

16

2

$-$

$-$

23

-

$0.0-$

0.0

0.0

0.1

0.0

$-$

0.5

0.0

0.0

$-$

0.3

0.4

-

0.0

0.0

-

-

-

-

$-$

0.0

$-$

$-$

$-$

$-$

0.0

0.0

0.0

-

1.4

0.8

0.0

0.0

$-$

$-$

$-$

0.1

0.0

$-$

0.2

0.1

$-$

0.2

0.1

1.7

2.0

1.8

-

-

0.1

0.2

0.1

0.5

0.1

0.7

0.1

12.8

0.0

10.0

$-$

0.0

7.6

$-$

0.3

$-$

0.0

1.7

1.1

-

-

0.8

0.5

0.2

0.1

$-$

0.1

0.1

$-$

$-$

0.4

0.5

0.1

$-$

0.0

0.0

2.7

$-$

1.2

0.0

1.8

0.0

6.6

47.9

4.0

33.4

0.1

41.3

$-$

0.0

0.1

0.0

0.2

0.0

0.4

0.3

0.0

$-$

0.0

$-$

$-$

0.0

0.0

4.5

11.7

$-$

0.0

8.4
0.0 
Yleisyysprosentti

Lounais- Väli-

Suomi Suomi

Frequency-\%

South- Middle

west

Finland
$\mathrm{Kpl} / \mathrm{m}^{2}$ kaikilla lohkoilla

Koko Lounais- Väli- Koko

Suomi Suomi Suomi Suomi No. $/ m^{2}$ on all the fields

Whole South- Middle Whole Finland west Finland Finland Finland
Hieracium spp.

Hypericum maculatum

Juncus bufonius

$J$. filiformis

Juncus spp.

Knautia arvensis

Lamium hybridum

L. purpureum

Lapsana communis

Lathyrus palustris

L. pratensis

Leontodon autumnalis

Linaria vulgaris

Lolium spp.

Luzula spp.

Lysimachia vulgaris

Maianthemum bifolium

Matricaria spp.

Melampyrum spp.

Mentha arvensis

Moehringia trinervia

Myosotis arvensis

M. stricta

Myosurus minimus

Oxalis acetosella

Phleum pratense

Phragmites communis

Picea abies

Pimpinella saxifraga

Pinus silvestris

Plantago major

Plantago spp.

Poa annua

$P$. palustris

$P$. pratensis s. lat.

$P$. trivialis

Poa spp.

Polygonum aviculare s. lat.

$P$. convolvulus

$P$. hydropiper

P. lapathifolium

Potentilla anserina

$P$. argentea

$P$. erecta

$P$. norvegica

Potentilla spp.
2

1

2

$-$

$-$

$-$

4

3

43

$-$

6

2

-

-

-

$-$

$-$

76

$-$

1

$-$

53

1

24

$-$

28

1

$-$

$-$

$-$

1

$-$

1

$-$

15

8

6

72

63

3

16

1

$-$

-

$-$

\begin{tabular}{|c|c|c|}
\hline 0.3 & 0.1 & 0.1 \\
\hline- & 0.0 & 0.0 \\
\hline 0.0 & 0.8 & 0.4 \\
\hline- & - & - \\
\hline- & 0.0 & 0.0 \\
\hline- & - & - \\
\hline 0.3 & 0.0 & 0.1 \\
\hline 0.2 & 0.0 & 0.1 \\
\hline 4.0 & 6.8 & 5.5 \\
\hline- & 0.0 & 0.0 \\
\hline 0.2 & 0.2 & 02 \\
\hline 0.0 & 0.6 & 0.3 \\
\hline- & - & - \\
\hline- & - & - \\
\hline- & 0.2 & 0.1 \\
\hline- & - & - \\
\hline- & - & - \\
\hline 12.9 & 5.7 & 9.0 \\
\hline- & 0.0 & 0.0 \\
\hline- & - & - \\
\hline- & 0.1 & 0.1 \\
\hline 4.7 & 9.7 & 7.4 \\
\hline- & - & - \\
\hline 3.1 & 3.2 & 3.1 \\
\hline- & 0.0 & 0.0 \\
\hline 5.0 & 10.9 & 8.2 \\
\hline- & - & - \\
\hline- & 0.0 & 0.0 \\
\hline- & - & - \\
\hline- & 0.0 & 0.0 \\
\hline 0.0 & 0.0 & 0.0 \\
\hline- & 0.0 & 0.0 \\
\hline 0.3 & 4.2 & 2.4 \\
\hline- & 0.1 & 0.1 \\
\hline 0.7 & 17.9 & 10.0 \\
\hline 1.6 & 5.5 & 3.7 \\
\hline 0.2 & 0.4 & 0.3 \\
\hline 7.2 & 7.4 & 7.3 \\
\hline 5.8 & 2.7 & 4.1 \\
\hline 0.1 & 1.5 & 0.9 \\
\hline 1.1 & 8.7 & 5.2 \\
\hline- & - & - \\
\hline- & - & - \\
\hline- & 0.0 & 0.0 \\
\hline- & 0.1 & 0.0 \\
\hline- & 0.0 & 0.0 \\
\hline
\end{tabular}




\begin{tabular}{llllll}
\hline Yleisyysprosentti & & \multicolumn{2}{l}{$\mathrm{Kpl} / \mathrm{m}^{2}$ kaikilla lohkoilla } \\
Lounais- Väli- & Koko & Lounais- Väli- Koko \\
Suomi Suomi & Suomi & Suomi Suomi Suomi \\
Frequency-\% & & No. $/ \mathrm{m}^{2}$ on all the fields \\
South- Middle & Whole & South- Middle Whole \\
west & Finland & Finland & west Finland Finland \\
Finland & & & Finland \\
\hline
\end{tabular}

Prunella vulgaris

Ranunculus acris s. lat.

$R$. auricomus coll.

R. flammula

$R$. polyanthemos

$R$. repens

Raphanus raphanistrum

Rhinanthus minor

Rhinanthus spp.

Ribes rubrum

Rorippa palustris

Rubus arcticus

Rumex acetosa s. lat.

$R$. acetosella s. lat.

$R$. longifolius

Rumex spp., suolaheinät - sorrels

Sagina procumbens

Salix spp.

Scleranthus annuus

Scutellaria galericulata

Senecio vulgaris

Silene cucubalus s. lat.

Solidago virgaurea

Sonchus arvensis

S. asper

Spergula arvensis

Stachys palustris

Stellaria graminea

$S$. media

Succisa pratensis

Taraxacum spp.

Thlaspi arvense

Trientalis europaea

Trifolium hybridum

T. pratense

T. repens

Triticum aestivum

Tussilago farfara

Untica dioica

Veronica agrestis

$V$. arvensis

V. chamaedrys

V. serpyllifolia

V. verna

Veronica spp.

Vicia cracca

12

315

$5 \quad 12$

- 1

$\begin{array}{ll}- & 1\end{array}$

$20 \quad 68$

$4 \quad 8$

11

1
$-\quad 2$

- 1

2

1

8

6

$-$

1

6

1

5

$-$

1

1

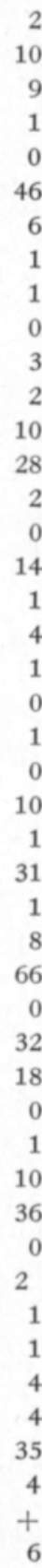

0.0

0.3

0.2

$-$

$-$

0.7

0.1

0.0

$-$

$-$

0.0

0.0

0.2

0.1

$-$

$-$

2.3

$-$

0.3

$-$

$$
0.0
$$$$
-
$$$$
\begin{aligned}
& 0.0 \\
& 0.3
\end{aligned}
$$

0.3

0.0

1.1

0.0

0.1

7.9

$-$

1.6

1.1

$-$

0.0

3.1

0.9

0.0

0.0

0.0

0.3

0.8

0.1

1.2

$-$

$-$

0.1
0.1

1.2

0.4

0.0

-

0.2

0.1

0.0

0.0

1.1

0.1

0.5

5.0

0.3

$-$

6.1

0.5

0.4

$-$

$-$

$-$

0.2

0.2

-

8.0

0.0

0.0

4.8

0.2

0.0

$13.2 \quad 10.8$

$-\quad-$

3.7

2.8

2.1

1.7

$-$

0.0

0.6

1.7

$\begin{array}{ll}3.7 & 2.4\end{array}$

3.7
$-\quad 0.0$

$\begin{array}{ll}0.0 & 0.0\end{array}$

$\begin{array}{ll}0.0 & 0.0\end{array}$

$\begin{array}{ll}0.0 & 0.1 \\ - & 0.5\end{array}$

$\begin{array}{ll}0.3 & 0.5\end{array}$

$\begin{array}{ll}0.1 & 0.1\end{array}$

$\begin{array}{ll}7.6 & 4.7\end{array}$

$\begin{array}{ll}0.5 & 0.2\end{array}$

$\begin{array}{ll}0.0 & 0.0\end{array}$

$0.1 \quad 0.1$

Continued 


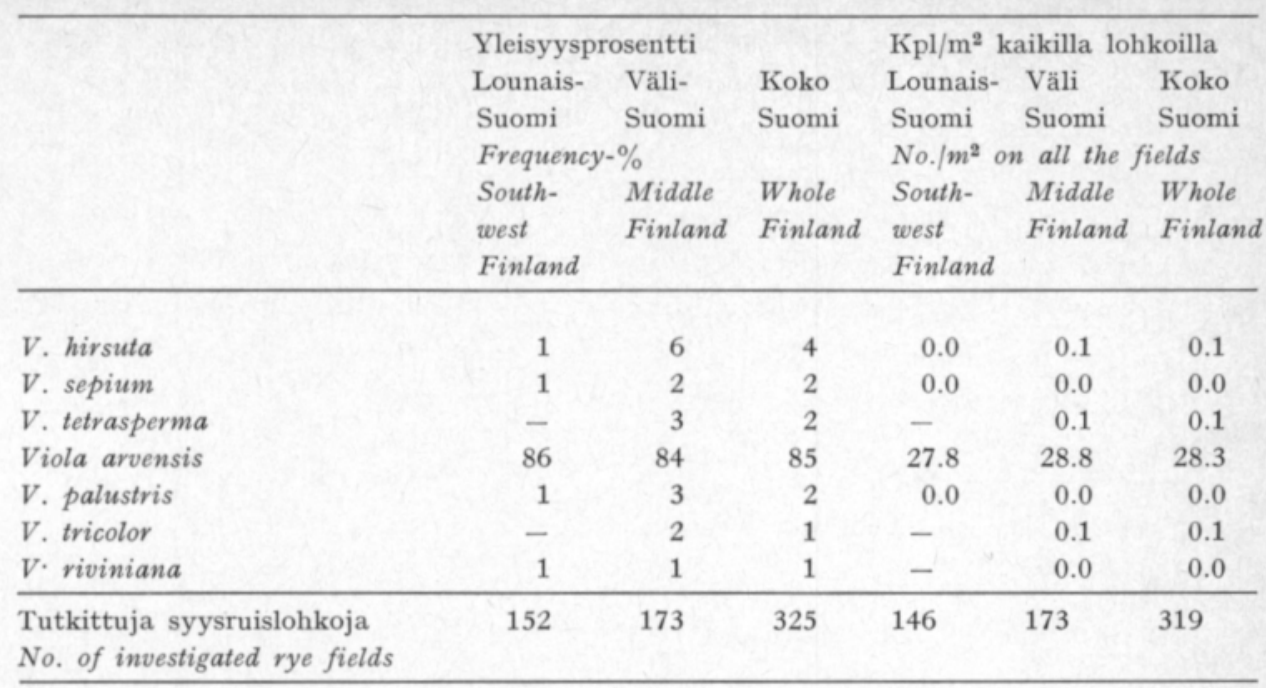

\section{2. 2. Lajike}

Ruislajike saatiin selville 300 tutkitulta lohkolta, joista 148 oli LounaisSuomen alueelta. Yleisimmät lajikkeet olivat Ensi, Toivo, Pekka ja Voima (taulukko 2), jotka olivat myös Maatalouden vuositilastojen mukaan yleisimmät ruislajikkeet. Näistä lajikkeista v. 1933 kauppaan lasketun hyvin talvea kestävän Ensin viljely oli keskittynyt Väli-Suomen alueen itä- ja keskiosaan paksulumisille alueille. Lajikkeen viljelyosuus on pysynyt viime vuosikymmeninä jokseenkin samansuuruisena. V. 1931 kauppaan lasketun Toivonkin viljely oli keskittynyt Väli-Suomen alueelle, mutta Ensiä heikomman talvenkestävyyden takia sen länsiosaan. Osittain sitä viljeltiin Lounais-Suomen alueenkin länsiosassa. Tämän lajikkeen osuus on pienentynyt viime vuosikymmeninä. Väli-Suomessa viljeltiin myös talvea hyvin kestävää Vjatkaa. V. 1941 kauppaan lasketun, heikosti talvea kestävän Pekan viljely oli keskittynyt Lounais-Suomen alueen länsiosaan ja osittain Väli-Suomen alueenkin länsiosaan. Pekan osuus on viime vuosikymmeninä kasvanut, mutta alkanee pienetä, koska v. 1966 kauppaan laskettu Voima valtaa alaa Lounais-Suomen alueella. Voimakin on heikosti talvea kestävä, eikä sitä voida viljellä paksulumisilla alueilla ainakaan ilman fungisidikäsittelyä. Pienijyväisten, heikkosatoisten maatiaisrukiiden viljely on vähentynyt jatkuvasti, mutta talvenkestävyyden ja tähkäidännän kestävyyden ansiosta niiden viljelyllä oli vielä melkoinen merkitys paksulumisella Väli-Suomen alueella. Viljely oli keskittynyt yleensä suositetuimpiin lajikkeisiin (vrt. esim. KonSALA 1971, KöyLıJÄrvi 1971).

\section{2. 3. Kylvösiemenen peittaus}

Kylvösiemenen peittauksesta saatiin tiedot 319 lohkolta, joista 148 oli Lounais-Suomen alueelta ja loput Väli-Suomen alueelta.

Rukiista peitattiin noin puolet. Peittaus oli yleisempää Lounais-Suomessa kuin Väli-Suomen (taulukko 2). Talvituhosieniä, etenkin lumihometta, 
Fusarium nivale (Fr.) Ces., on torjuttu kestäviä maatiaisrukiita sekä Ensiä ja Toivoa viljelemällä sekä välttämällä aikaista kylvöä ja runsasta typpilannoitusta syksyllä. Peittaus elohopealla ja benomyylillä oli tutkimuskautena yleistymässä. Myyntitilastojen mukaan kyseisenä kautena noin $\mathbf{5 8} \%$ leipävilja-alasta kylvettiin peitatulla siemenellä (MARKKula 1973, 1974, MARKKuLA ja TiIttanen 1975). Tässä käyttötutkimuksessa päädyttiin suunnilleen samaan tulokseen. Peittausta olisi ehkä tullut käyttää useammin kuin viljelijät sitä käyttivät, sillä silloin olisi voitu viljellä Väli-Suomessakin satoisampia eteläisemmän vyöhykkeen lajikkeita (JAMALAInen 1962, Hänninen ja Jamalainen 1968).

\section{2. 4. Kylvösiemenmäärä}

Rukiin kylvösiemenmäärä saatiin selville 321 lohkolta, joista 148 oli LounaisSuomen alueella ja 173 Väli-Suomen alueella. Keskimääräinen kylvösiemenmäärä koko maassa oli $193 \mathrm{~kg} / \mathrm{ha}$, ja se oli Lounais-Suomessa $12 \mathrm{~kg}$ suurempi kuin Väli-Suomen alueella (taulukko 2). Eroa ei selitä pelkästään mahdollinen siemenen painon ero, vaan Lounais-Suomen alueella ruis ilmeisesti kylvettiin tiheämmäksi kuin Väli-Suomen alueella.

Syysrukiin kylvösiemenmääräksi suositeltiin n. $150-160 \mathrm{~kg} / \mathrm{ha}$ (VALLE 1962, KöyliJÄRvi 1974) tai $160-180 \mathrm{~kg} /$ ha (LAMpinen 1971). Tämä tutkimus osoitti, että viljelijät käyttivät suositeltua suurempaa kylvösiemenmäärää, sillä itävyys oli tutkimusvuosina Valtion Siementarkastuslaitoksen mukaan keskimäärin $87 \%$ ja peittaus kohotti itävyyttä 1.6 prosenttiyksikköä. Kun lisäksi rukiin jyvä oli tutkimuskautena monin paikoin melko pieni, johti liian suuren siemenmäärän käyttö tiheisiin ja aikaisin lakoutuviin kasvustoihin, esim. v. 1972.

\section{2. 5. Kylvöaika}

Rukiin kylvöaika saatiin selville 308 lohkolta, joista 147 oli Lounais-Suomen ja 161 Väli-Suomen alueella.

Ruista kylvettiin tutkimustiloilla lähes kahden kuukauden aikana, 2. VIII -25. IX. Keskimääräinen kylvöaika oli koko maassa 25. elokuuta. VäliSuomen alueella se oli jo 23. elokuuta ja Lounais-Suomen alueella 27. e1okuuta. Neuvonnassa on jatkuvasti kiinnitetty huomiota rukiin oikeaan kylvöaikaan. Liian varhain kylvetyissä rukiissa kahukärpänen (Oscinella frit L.) sekä ruosteja härmäsienet alentavat satoa ja liian myöhään kylvetyissä ruis jää heikoksi ja talvehtimisvaurioiden riski kasvaa. Tutkimusten mukaan (ANTTINEN 1958, HonkavaAra 1958, Linnomäki 1958, Valle 1958, Hakkola 1966, Yllö 1969, Köylijärvi 1974, Marjanen 1975, Mukula et al. 1976, SimoJOKI 1976) paras kylvöaika on koko maassa noin 25.-27. elokuuta. VäliSuomessa se on muutamaa päivää aikaisempi ja eteläosissa muutamaa päivää myöhäisempi. Viljelijöiden noudattama keskimääräinen kylvöaika oli jokseenkin oikea. Hajonta oli kuitenkin suuri (taulukko 2), joten kaikilla tiloilla ei saatu parasta mahdollista satoa. Kylvökautta tulisi lyhentää, ja jos kahukärpäs- ja talvituhosieniruiskutuksia tehdään tulevaisuudessa nykyistä enemmän, kylvöaikaa voitaisiin siirtää muutama päivä aikaisemmaksi. 


\section{3. Hoitotavat}

\section{3. 1. Kahukärpästen torjunta}

Kahukärpästen torjuntaa on viime vuosikymmeninä tehostettu siirtymällä myöhäisempään kylvöaikaan. Vuosisadan alussahan suositeltiin kylvöjen aloituspäiväksi 10. elokuuta (SUnILA et al. 1915), mutta myöhemmin suositeltiin kylvöajaksi Etelä- ja Keski-Suomessa elokuun viimeistä viikkoa (VALLE 1962) tai 25.-27. elokuuta (MARJANEN 1975). Kylvöajan siirtämisestä noin kaksi viikkoa myöhäisemmäksi on ollut seurauksena kahukärpäsvioitusten vähentyminen ilmeisesti noin 40-prosenttisesta vioituksesta alle 20-prosenttiseen vioitukseen laskettuna TirtTASEN (1959) ilmoittamista vioitusluvuista. Samanaikaisesti on rukiin hehtaarisato kohonnut useimpina vuosina useita satoja kiloja. Kemiallista torjuntaakin on suositeltu, mutta se oli erittäin harvinaista: ainoallakaan tutkitulla lohkolla ei ollut tehty kemiallista tuhoeläintorjuntaa. Kun eräät kylvöt oli tehty varsin aikaisin, olisi kahukärpäsen torjunta ilmeisesti antanut varsinkin Lounais-Suomessa, mutta myös VäliSuomessa huomattavan sadon lisäyksen (Sıмојокі 1976). Aikaisempaan kylvöön siirtyminen samalla varmistaisi, ettei liiallinen kosteus tee kylvöä hankalaksi.

\section{3. 2. Talvituhosienten torjunta orasasteella}

Talvituhosienet torjutaan tavallisesti viljelemällä kestäviä lajikkeita tai peittaamalla siemen. Torjunta voidaan tehdä myös orasasteella marraskuun loppupuolella. Tämä torjuntatapa oli kuitenkin hyvin harvinaista, ja tutkimuslohkoilla vain yksi lumihomeelle verraten alttiilla lajikkeella kylvetty lohko Orivedellä oli käsitelty kvintotseeniä sisältävällä Avicolilla. Kvintotseeni-käsittely lisää satoa varsinkin aikaisissa kylvöissä (SIмоJoKI 1976), ja käsittelyä suositeltiin runsaslumisella alueella kaikille ruislajikkeille (LuostARINEN 1969). Mitä myöhemmin kvintotseenikäsittely tehdään ennen lumen tuloa, sitä suurempi sato saadaan (Jamalainen 1958, 1964, MarJanen 1975). Sisämaassa torjunnan olisi pitänyt olla yleisempää varsinkin lumihomeelle alttiita lajikkeita, kuten Pekkaa viljeltäessä.

\section{3. 3. Talvilannoitus}

Kuivina keväinä typpilannoitus saattaa tulla toisinaan liian myöhään rukiin käyttöön. Ongelman ratkaisemiseksi typen levitystä on kokeiltu syys- ja talvikautena ja todettu, että vähäsateisena keväänä typen talvilevitys saattaa antaa suuremman jyväsadon kuin kevätlevitys (PEssi 1969, 1970). Tiedon julkistaminen johti tavan käyttöönottoon. Talvilannoitusta tehtiin $1 \%$ :lla tutkituista lohkoista (taulukko 2) ja $1.5 \%$ :lla syysrukiin viljelyalasta. Useina vuosina talvilannoitus antoi kuitenkin kevätlannoitusta pienemmän sadon (Pessi 1969, 1970, KöYliJ̈̈Rvi 1972).

\section{3. 4. Kevätlannoitus}

Keväällä rukiille suositellaan täydennyslannoituksena etenkin typpeä, jota sille ei voida antaa peruslannoituksena riittävää määrää oraiden tuhoutumisen takia (esim. KöYLIJÄRvi 1975). Rukiin kevätlannoituksesta saatiin tiedot 
318 lohkolta, joista 147 oli Lounais-Suomen ja 171 Väli-Suomen alueelta. Selvitys (taulukko 2) osoittaa, että $70 \%$ ruislohkoista sai keväällä typpilannoituksen, tavallisesti Oulunsalpietarina. Lounais-Suomessa lannoitus oli yleisempää ja lannoitemäärät suurempia kuin Väli-Suomen alueen multavilla ja kevyillä mailla. Typpimääräksi suositellaan $0-100 \mathrm{~kg} / \mathrm{ha}$ maan laadun ja esikasvien mukaan (PEssi 1970). Tulokset osoittavat, että viljelijät käyttivät typpeä näissä rajoissa. Hyväkuntoiselle oraalle aikaisin annetusta typestä oli toisinaan seurauksena lakoutuminen (VARIS 1976). Kevätroutaiselle orasmaalle suositeltiin kuitenkin tutkimuskautena jopa $200-300 \mathrm{~kg} / \mathrm{ha}$ Oulunsalpietaria (KARES 1973). Suuren typpimäärän käyttö olisi edellyttänyt samalla nykyaikaisempaa viljelytekniikkaa, mm. herbisidien ja korrenvahvisteen käyttöä, jotka usein laiminlyötiin.

\section{3. 5. Rikkaruohoruiskutus}

Tietoja saatiin 318 lohkolta; näistä 148 oli Lounais-Suomen ja 170 VäliSuomen alueella. Kemiallinen rikkaruohontorjunta tehtiin aina ruiskuttamalla.

Koko maassa käsiteltiin herbisideillä vain neljännes ruislohkoista (taulukko 2), ja käsittelyt olivat Lounais-Suomen alueella yleisempiä kuin VäliSuomen alueella. Ruislohkojen pinta-alasta käsiteltiin Lounais-Suomen alueella $40.6 \%$, Väli-Suomen alueella $18.1 \%$ ja koko maassa $32.7 \%$. Torjuntaaineiden myyntitilastojen mukaan (MarkKula 1973, 1974, MarkKUla ja TIITTANEN 1975) viljakasvien kokonaispinta-alasta voitiin käsitellä tutkimuskautena $68 \%$ MCPA:lla tai vastaavilla aineilla. Rukiista, joka on hyvin kilpailukykyinen rikkaruohoja vastaan, torjuttiin täten paljon harvemmin rikkaruohoja kuin muista viljoista.

Ruiskutusajaksi suositellaan varhaista kevättä, kun ilman lämpötila on torjunta-aineesta riippuen yli 7 tai yli 10 astetta (M. RAATIKAINEN et al. 1971). Rikkaruohoruiskutus tehtiin yleensä oikeaan aikaan (taulukko 2), mutta osa viljelijöistä suoritti käsittelyn liian myöhään, jolloin torjunta-aineista dikamba, 2,3,6-TBA ja diklorproppi vioittivat ruista.

Ruiskutus tehtiin Lounais-Suomen alueella aina traktoriruiskulla. VäliSuomen alueella $81 \%$ käsitellyistä lohkoista ruiskutettiin traktoriruiskulla ja $19 \%$ työnnettävällä kärryryiskulla. Koko maassa $95 \%$ käsitellyistä lohkoista ruiskutettiin tarktoriruiskulla ja $5 \%$ kärryruiskulla. Kärryruiskulla käsitelty pinta-ala oli vain $0.9 \%$ koko käsitellystä ruisalasta.

Rikkaruohoruiskutukseen aikaisemmin yleisesti käytetyn MCPA:n teho oli ERvıön (1976) mukaan syysitoisten rikkaruohojen lukumäärään vain $29 \%$ ja painoon $21 \%$. Kevätitoisiin teho oli parempi, $50 \%$ ja $43 \%$ vastaavasti. Kun syysitoisten määrät olivat runsaita ja MCPA:ta oli käytetty monilla lohkoilla pitkän aikaa, oli kevätitoisten lajisto muuttunut MCPA:ta kestävämmäksi. Niinpä MCPA:lla voitiin hävittää eräillä Lounais-Suomen alueilla vain $3 \%$ rukiin rikkakasvien painosta (ERvıö 1976). Tällaisesta rikkaruoholajiston koostumuksen muutoksesta ja yhä heikommasta torjuntatuloksesta on aiheutunut siirtyminen seoksiin, joiden teho on parempi kuin pelkän MCPA:n. Seosten käyttö yleistynee edelleen koko maassa ja sen tulisi tapahtua melko nopeasti varsinkin talouskeskusten lähipelloilla. 
Traktoriruiskuilla tehdyissä rikkaruohokäsittelyissä käytettiin vettä Lounais-Suomen alueella keskimäärin 236, Väli-Suomen alueella keskimäärin 222 ja koko maassa keskimäärin $233(180-400)$ 1/ha (taulukko 2). Työnnettävissä kärryruiskuissa vettä käytettiin keskimäärin 248 1/ha. Käyttömäärät olivat yleensä suositusten mukaisia. Eniten käytettiin alimpia suositeltuja nestemääriä. Kosketusvaikutteisia aineita rehevässä ruiskasvustossa käytettäessä vesimäärä olisi saanut olla eräissä tapauksissa suurempi.

\section{3. 6. Korrenvahvisteen käyttö}

Klormekvattikloridin käyttö korren vahvistamiseen on ollut Suomessa sallittua vuodesta 1965 alkaen. Pitkä- ja heikkokortisen rukiin korren vahvistamiseen sen käyttö alkoi myöhemmin, ja sitä käytettiin v. 1973-1974 tutkituista lohkoista $15 \%$ :lla (taulukko 2). Käyttö oli yleisintä Lounais-Suomen alueella. Klormekvatin käyttöön suhtauduttiin aluksi varauksellisesti eikä sitä uskallettu selvästi suositella (Mukula ja Teittinen 1967, Yllö 1967), mutta varsinkin Itä-Suomessa tehtyjen kokeiden perusteella sitä alettiin suositella (LUostarinen 1969, 1971, Anon. 1975). Klormekvatti myöhästyttää ja vähentää lakoutumista, kohottaa jyväsatoa ja parantaa sen laatua (VARIS 1976). Käytöstä ei kuitenkaan olla yksimielisiä.

\section{4. Rukiin käyttö suojaviljana}

Ruis oli viime vuosisadalla ja tämän vuosisadan alussa tavallisin nurmien suojakasvi (von Essen 1913, Grotenfelt ja Puhakka 1914, Sunila et al. 1915), ja sitä pidettiin parhaiten tähän tarkoitukseen sopivana. Vähitellen alettiin luopua rukiista suojaviljana, mm. lakoutumisen takia, viljelyalan pienentymisen ja siementen peittämisvaikeuksien takia, ja suositeltiin kevätviljoja nurmien suojakasviksi (WALLE 1929). Tämä tapa yleistyi nopeasti, ja v. 1951 ruista käytettiin enää $11 \%$ :lla perustetusta nurmialasta suojakasvina (PAatela 1953) ja v. 1966-1968 enää $2 \%: l l a$ (M. RaAtikainen ja T. RaAtiKAINEN). Tämän tutkimuksen mukaan ruislohkoista oli $3 \%: 1 l a$ nurmikylvös alla (taulukko 2) ja ruisalasta oli Lounais-Suomen alueella $0.3 \%$, Väli-Suomen alueella $2.1 \%$ ja koko maassa $0.9 \%$ nurmien suojaviljana.

\section{5. Rikkaruoholajit, niiden yleisyys ja yksilötiheys}

\section{5. 1. Lajisto ja yleisyys}

Tutkituista 325 ruispellosta löydettiin ainakin 176 putkilokasvilajia, jos taulukossa 3 ja tekstissä mainitut lajit lasketaan yhteen. Lajimäärä oli VäliSuomen alueella, etenkin sen itäosassa, suurempi kuin Lounais-Suomen alueella. Vertailu kevätviljapelloista ja heinänurmista tavattuun lajimäärään (MuKuLA et al. 1969, M. RaAtikainen ja T. RAAtikAinen 1975) osoittaa, että ruispeltojen lajimäärä oli ehkä vähän pienempi kuin kevätviljapeltojen lajimäärä ja useita kymmeniä lajeja pienempi kuin vastaavalta heinänurmilohkomäärältä tavattu lajimäärä. Yhteisenä piirteenä oli, että kaikkien näiden viljelykasvien lohkoilla lajimäärä oli Itä-Suomessa suurempi kuin Länsi-Suomessa. Tätä ilmiötä ja sen syitä on pohdittu aikaisemmin (M. RAATIKAINEN ja T. RAAtiKAINEN 1975, M. RAATIKAINEN et al. 1979). 
Syysruislohkoilta tavatuista rikkaruohoista 170 lajia kyettiin jakamaan yleisyysprosenttiluokkiin seuraavasti:

\begin{tabular}{|c|c|c|c|c|c|}
\hline Yleisyysprosentti & $\begin{array}{c}\text { Kevät- } \\
\text { yksivuotiset }\end{array}$ & $\begin{array}{c}\text { Syys- } \\
\text { yksivuotiset }\end{array}$ & $\begin{array}{c}\text { Kaksi- } \\
\text { vuotiset }\end{array}$ & $\begin{array}{c}\text { Moni- } \\
\text { vuotiset }\end{array}$ & Yhteensä \\
\hline$-2 \ldots \ldots \ldots \ldots \ldots \ldots \ldots \ldots \ldots \ldots$ & 11 & 14 & 5 & 71 & 101 \\
\hline $3-4 \ldots \ldots \ldots \ldots \ldots \ldots . .$. & 3 & 4 & - & 9 & 16 \\
\hline $5-8 \ldots \ldots \ldots \ldots \ldots$ & 3 & 1 & - & 6 & 10 \\
\hline 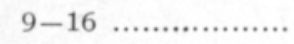 & 2 & 3 & - & 10 & 15 \\
\hline $17-32 \ldots \ldots \ldots \ldots \ldots$ & 2 & 2 & - & 4 & 8 \\
\hline $33-64 \ldots \ldots \ldots \ldots \ldots \ldots$ & 4 & 2 & - & 8 & 14 \\
\hline $65-\quad$ (n................. & 3 & 3 & - & - & 6 \\
\hline
\end{tabular}

Yleisimmät kevätyksivuotiset kasvit ja niiden yleisyysprosentit olivat seuraavat: Chenopodium album 86, Galeopsis spp. 85 (kyseessä lienee suurinpiirtein G. bifidan yleisyysprosentti), Erysimum cheiranthoides 72, Polygonum aviculare 64, P. convolvulus 53, Gnaphalium uliginosum 35 ja Polygonum lapathifolium 34. Yleisimmät lajit ja niiden yleisyysprosentitkin ovat jokseenkin samat kuin kevätviljapelloissa (vrt. Mukula et al. 1969). Huomattavimmat erot olivat $P$. avicularen 22 prosenttiyksikköä suurempi yleisyysprosentti syysrukiissa kuin kevätviljoissa ja Spergula arvensiksen 57 ja P. lapathifoliumin 38 prosenttiyksikköä pienempi yleisyysprosentti syysrukiissa kuin kevätviljoissa.

Yleisimmät syysyksivuotiset kasvit ja niiden yleisyysprosentit olivat seuraavat: Viola arvensis 85, Stellaria media 66, Matricaria spp. 65, joka lienee lähes kokonaan Tripleurospermum inodorumia, Myosotis arvensis 60 ja Lapsana communis 41. Tässäkin tapauksessa syysrukiin ja kevätviljojen yleisimmät rikkaruoholajit sekä niiden yleisyysprosentit olivat lähes samat. Olennaisimmat erot olivat Tripleurospermum inodorumin suurempi yleisyysprosentti syysrukiissa kuin kevätviljoissa ja Stellaria median 19 prosenttiyksikköä alhaisempi yleisyysprosentti syysrukiissa kuin kevätviljoissa.

Monivuotisista kasveista olivat yleisimmät Ranunculus repens 46, Agrostis spp. 42, joka oli lähes yksinomaan A. tenuista, Cerastium caespitosum 42, Phleum pratense 41, Agropyron repens 39, Poa pratensis 36, Trifolium repens 36 ja Veronica serpyllifolia 35 . Tämä lajisto poikkesi huomattavasti kevätviljojen vastaavasta yleisimmästä lajistosta sekä lajikoostumukseltaan että runsaussuhteiltaan. Syysrukiin yleisimmat lajit olivat etupäässä tyypillisiä nurmien kasveja, jotka jäivät syysviljoihin vähäisen muokkauksen ja pian sen sen jälkeen tehdyn kylvön takia. Kevätviljoissa tällä lajistolla ei ollut yhtä suurta mahdollisuutta esiintyä, koska nurmet kynnettiin tavallisesti syksyllä ja talven aikana nurmikasvit usein kuolivat. Kylvömuokkauksen jälkeen enää harvat nurmikasvit olivat elossa. Kevätviljoissa taas olivat yleisiä nopeasti itävät tai muokkausta kestävät avoviljelysten kestorikkaruohot kuten Ranunculus repens ja Agropyron repens.

3. 5. 2. Rikkaruohojen tiheys kaikilla lohkoilla

Syysruislohkoilla oli keskimäärin 303 rikkaruohoa $/ \mathrm{m}^{2}$. Tiheys oli LounaisSuomen alueella $214 \mathrm{kpl} / \mathrm{m}^{2}$ ja Väli-Suomen alueella $378 \mathrm{kpl} / \mathrm{m}^{2}$. Koko maan 
tiheys oli vain $55 \%$ kevätviljapeltojen rikkaruohotiheydestä $550 \mathrm{kpl} / \mathrm{m}^{2}$ (vrt. Mukula et al. 1969). Syysruislohkojen 170 edellä mainittua rikkaruoholajia jakaantuivat yksilö- tai versotiheyden perusteella tiheysluokkiin seuraavasti:

\begin{tabular}{|c|c|c|c|c|c|}
\hline $\begin{array}{l}\mathrm{Kpl} / \mathrm{m}^{2} \text { kaikilla } \\
\text { lohkoilla }\end{array}$ & $\begin{array}{c}\text { Kevät- } \\
\text { yksivuotiset }\end{array}$ & $\begin{array}{c}\text { Syys- } \\
\text { yksivuotiset }\end{array}$ & $\begin{array}{l}\text { Kaksi- } \\
\text { vuotiset }\end{array}$ & $\begin{array}{l}\text { Moni- } \\
\text { vuotiset }\end{array}$ & Yhteensä \\
\hline$-2 \ldots \ldots \ldots \ldots \ldots \ldots$ & 18 & 22 & 5 & 97 & 142 \\
\hline $3-4 \ldots \ldots \ldots \ldots \ldots \ldots \ldots$ & 3 & 2 & - & 5 & 10 \\
\hline 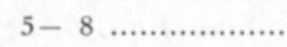 & 4 & 2 & - & 2 & 8 \\
\hline $9-16$ …............... & 1 & 2 & - & 4 & 7 \\
\hline $17-32 \ldots \ldots \ldots \ldots \ldots$ & 1 & 1 & - & - & 2 \\
\hline $33-64 \ldots \ldots \ldots \ldots \ldots \ldots$ & 1 & - & - & - & 1 \\
\hline
\end{tabular}

Tiheimmässä kasvaneet kevätyksivuotiset rikkaruohot, niiden yksilötiheydet ja osuudet koko yksilömäärästä käyvät ilmi seuraavasta asetelmasta:

$\begin{array}{lrr} & \mathrm{Kpl} / \mathrm{m}^{2} & \% \\ \text { Galeopsis spp. } & 46.5 & 15.4 \\ \text { Chenopodium album } & 27.4 & 9.1 \\ \text { Erysimum cheiranthoides } & 10.0 & 3.3 \\ \text { Gnaphalium uliginosum } & 8.4 & 2.8 \\ \text { Polygonum aviculare } & 7.3 & 2.4 \\ \text { P. lapathifolium } & 5.2 & 1.7 \\ \text { Spergula arvensis } & 4.8 & 1.6\end{array}$

Galeopsis-suvun lajeja syysrukiissa oli kolme; näistä G. bifida ja G. speciosa olivat runsaimmat ja $G$. tetrahit edellisiä huomattavasti niukempana esiintyvä laji. Runsaimpana kasvava kevätyksivuotisten lajisto oli jokseenkin sama kuin kevätviljoissakin. Yksilötiheydet olivat kuitenkin vain noin puolet kevätviljoissa todetusta tiheydestä, ja osuudet koko yksilömäärästä olivat hyvin samanlaisia molemmissa viljoissa. Huomattavimpia poikkeuksia olivat $S$. arvensis, jonka osuus oli syysrukiissa vain kymmenesosa siitä, mitä se oli kevätviljoissa ja $P$. aviculare, jonka osuus oli syysrukiissa noin viisinkertainen kevätviljoissa olevaan verrattuna. Vertailu sokerijuurikasmaiden rikkaruoholajistoon osoitti, että runsaussuhteet olivat hyvin erilaiset (vrt. BRUMMER et al. 1971).

Syysyksivuotisista olivat runsaimpina:

$\begin{array}{lcr} & \mathrm{Kpl} / \mathrm{m}^{2} & \% \\ \text { Viola arvensis } & 28.3 & 9.4 \\ \text { Stellaria media } & 10.8 & 3.6 \\ \text { Matricaria } \text { spp. } & 9.0 & 3.0 \\ \text { Myosotis arvensis } & 7.4 & 2.4 \\ \text { Lapsana communis } & 5.5 & 1.8\end{array}$

Matricaria-sukuun on tässä luettu kolme lajia, joista runsain oli Tripleurospermum inodorum ( $M$. perforata), toiseksi runsain $M$. matricarioides (Chamomilla suaveolens) ja näitä huomattavasti harvinaisempi $M$. recutita (Chamomilla $r$.)

Tiheimmässä kasvaneet syysyksivuotiset rikkaruohot olivat $T$. inodorumia lukuun ottamatta samoja kuin kevätviljoissa (vrt. MukULA et al. 1969), mutta 
syysrukiissa suhteellinen tiheys ja toisinaan myös yksilömäärät pinta-alayksikköä kohden olivat suuremmat kuin kevätviljoissa. Edellä mainituista lajeista vain $S$. median ja $L$. communiksen osuudet koko rikkakasviyksilöiden määrästä olivat syysrukiissa pienempiä kuin kevätviljoissa. Sokerijuurikasmaiden syysitoisten lajien koostumus erosi rukiin rikkaruohokoostumuksesta enemmän kuin kevätviljojen (vrt. BRUMmer et al. 1971).

Kestorikkaruohoista olivat rukiissa runsaimpina:

$\begin{array}{lcc} & \mathrm{Kpl} / \mathrm{m}^{2} & \% \\ \text { Agrostis spp. } & 15.6 & 5.2 \\ \text { Agropyron repens } & 12.9 & 4.3 \\ \text { Poa pratensis } & 10.0 & 3.3 \\ \text { Ranunculus repens } & 9.9 & 3.3 \\ \text { Phleum pratense } & 8.2 & 2.7 \\ \text { Veronica serpyllifolia } & 4.7 & 1.6\end{array}$

Rölleistä oli suurin osa Agrostis tenuista, mutta joukossa oli myös A. gigantea, A. canina ja A. stolonifera. Viljelykasvien $P$. pratensen ja Trifolium pratensen suuret tiheydet aiheutuivat osaksi nurmikylvöistä, mutta huomattavalta osalta kuitenkin näiden kasvien säilymisestä joko siemeninä tai vanhoina yksilöinä pelloilla. Esimerkiksi $P$. pratensen yksilöistä oli $19.4 \%$ ja $T$. pratensen yksilöistä $0.2 \%$ vähintään vuoden ikäisiä kasveja; näistä varsinkin timotein vanhat yksilöt olivat merkittäviä kilpailijoita rukiin kanssa.

Rukiin vallitseva kestorikkaruoholajisto erosi melkoisesti kevätviljojen vastaavasta lajistosta (vrt. Mukula et al. 1969). Etenkin heinänurmien tyypillisten lajien versotiheydet ja niiden osuudet olivat rukiissa suurempia kuin kevàtviljoissa (vrt. M. RaAtikainen ja T. RAatikainen 1975). Avoviljelysten kyntöäkestävien kestorikkaruohojen, joihin A. repenskin voidaan lukea, osuus oli syysrukiissa pienempi kuin kevätviljoissa.

\section{5. 3. Rikkaruohojen tiheys lajia kasvavilla lohkoilla}

Yksilö- tai versotiheys lajia kasvavilla lohkoilla oli korkeampi kuin tiheys/ kaikki tutkitut lohkot. Tällöin on kuitenkin huomattava, että niukkana esiintyviä lajeja ei läheskään aina havaittu ja että kaikki kenttätyöntekijät eivät tehneet huolellista työtä kirjatessaan näytealojen ulkopuolisia lajeja. Täten tiheydet saastuneilla lohkoilla tulivat liian korkeiksi ja varsinkin vaikeasti havaittavien pienikokoisten lajien tiheydet näyttivät olleen suuremmat kuin suurikokoisten helposti havaittavien lajien. Tulokset osoittivat kuitenkin, että muutamien lajien tiheydet olivat hyvin suuret, jos lajeja oli lohkolla. Tällaisia olivat mm. viljelykasvit Trifolium pratense ja Phleum pratense ja kylvämättä kasvavista lajeista mm. Deschampsia caespitosa sekä Lamium- ja Alopecurus-lajit, jotka ovat yleisimmin käytettyjä herbisidejä kestäviä lajeja.

Vertailtaessa rikkaruohojen tiheyttä saastuneilla lohkoilla syysrukiissa ja kevätviljapelloilla todetaan, että lajisto ja yksilötiheyksien suhteet ovat pääpiirteissään samanlaiset (vrt. Mukula et al. 1969). Spergula arvensiksen ja Stellaria median osuudet olivat kuitenkin kevätviljoissa paljon suuremmat ja kasvutiheydet usein noin kaksinkertaiset rukiissa oleviin verrattuna. 


\subsection{Rikkaruoholajien yksilötiheyteen vaikuttavista seikoista}

\section{6. 1. Tilan peltoala}

Pienten tilojen lohkot olivat pienempiä ja lähempänä talouskeskusta kuin suurten. Lisäksi viljelytavat, maalajit ym. seikat olivat erilaiset, ja mm. karjanlantaa käytettiin pienillä tiloilla yleisemmin kuin isoilla Useat tällaiset syyt aiheuttivat, että pienillä tiloilla olivat runsaimpina etenkin karjanlannan mukana kulkeutuvat, ravinteisten kivennäismaiden kasvit kuten Chenopodium album ja Stellaria media (taulukot 4 ja 5). S. media on todettu myös kevätviljapelloissa ja heinänurmissa pienten tilojen kasviksi, mutta $C$. album kevätviljoissa suurten tilojen kasviksi (Mukula et al. 1969, M. RaAtikainen ja T. RaAtikainen 1975). Suurilla tiloilla oli runsaampana vain Galeopsis bifida, joka on humuspitoisten takamaiden kasvi. Se on myös osaksi myöhään itävä ja saattoi menestyä siksi suurtiloilla, jotka ruiskuttivat yleensä ohjeiden mukaisesti mahdollisimman aikaisin. Galeopsis-suku, jonka runsain laji oli $G$. bifida, oli myös kevätviljoissa suurten tilojen kasvi (MukULA et al. 1969).

Taulukko 4. Eri ekologisten tekijöiden vaikutukset rikkaruohojen yksilö- tai versotiheyteen. Viimeisessä sarakkeessa ilmoitetaan luvulla, minkä tasojen vălillä on merkitsevä ero ja mikä on sen merkitsevyys. Tämä luku saadaan oheisesta asetelmasta. Jos ero on a:n ja b:n välillä sitä merkitään ykkösellä, jos se on c:n ja d:n välillä, sitä merkitään kuutosella.

Table 4. The influence of different ecological factors on the plant or shoot densities of the weeds. The number in the last column gives the levels between which there is a difference and the significance of the difference. This number derives from the attached setting. If there is a difference between $a$ and $b$, it is marked by number one, if it is between $c$ and $d$, it is marked by number six.

Tasot - Levels

\begin{tabular}{|c|c|c|c|}
\hline & b & c & d \\
\hline $\mathbf{a}$ & 1 & 2 & 4 \\
\hline b & & 3 & 5 \\
\hline c & & & 6 \\
\hline
\end{tabular}

Tasot ovat:

- maalajissa: a) karkea kivennäismaa - hiesu, b) savimaa ja c) eloperäinen maa,

- maaperän kosteudessa: a) poutiva, b) keskinkertainen ja c) veden vaivaama,

- esikasvissa: a) kevätvilja, b) syysvilja tai syysrypsi, c) nurmi ja d) muu kasvi tai kesanto,

- peittauksessa: a) ei, b) kyllä,

- karjanlannan käytössä syksyllä a) ei, b) kyllä

- alueessa: a) Lounais-Suomen alue, b) Väli-Suomen alue.

The levels are:

- in soil type: a) coarse mineral soil and silt, b) clay soil and c) organic soil

- in moisture conditions: a) dry, b) medium dry, c) wet

- in previous crop: a) spring cereal, b) winter cereal or winter turnip rape, c) ley and d) other plant or fallow

- in seed dressing: a) no, b) yes

- in farmyard manure in autumn: a) no, b) yes

- in locality: a) Southwest Finland, b) Middle Finland 
Index $:$ alue $=$ locality, esikasvi $=$ previous crop, karjanlannan määrä $=$ farmyard manure (tons), karjalanta syksyllä = farmyard manure in autumn, kosteus = moisture conditions of soil, kylvöaika $=$ sowing time, leikkuupuintien määrä $=$ number of combine harvesting, lohkon ikä peltona $=$ age of cultivated field, luokkamuuttujat $=$ class variables, maalaji $=$ soil type, nurmien määrä $=$ number of leys, peittaus $=$ seed dressing, regressiomuuttujat $=$ regression variables, rikkalaskennan päivä $=$ date of survey, rikkaruohoruiskutusten määrä $=$ number of herbicidal treatments, tilan peltoala $=$ farm arable area, typpilannoitus keväällä $=$ nitrogen fertilization in spring viljan peittävyys $=$ cover percentage of cereal.

$\begin{array}{lll}\text { d.f. } & \text { F } & \begin{array}{l}\text { Ero ja sen } \\ \text { merkitsevyys } \\ \text { Diff. between }\end{array}\end{array}$

Achillea millefolium

Luokkamuuttujat

Maalaji ......................................... $\quad 2,298$

$2,298 \quad 11.12 * * *$

Alue

Achillea ptarmica

Regressiomuuttujat

Rikkaruohoruiskutusten määrä.........

Luokkamuuttujat

Alue

Agropyron repens

Regressiomuuttujat

Rikkaruohoruiskutusten määrä $\ldots \ldots \ldots \ldots . . \quad 1,292$

$8.67 * *$

Kylvöaika ................................... 1,292

$25.83 * * *$

Nurmien määrä

Typpilannoitus keväällä

Lohkon ikä peltona

Luokkamuuttujat

Maalaji

Kosteus

Alue

Agrostis spp.

Regressiomuuttujat

Viljan peittävyys

Luokkamuuttujat

Maalaji

Alue

Alopecurus geniculatus

Luokkamuuttujat

Maalaji

Esikasvi

Capsella bursa-pastoris

Luokkamuuttujat

Maalaji

Peittaus

Karjanlanta syksyllä

Centaurea cyanus

Regressiomuuttujat

Nurmien määrä 
d.f. $\mathrm{F}$

Luokkamuuttujat

Maalaji

Cerastium caespitosum

Regressiomuuttujat

Leikkuupuintien määrä

Nurmien määrä

Luokkamuuttujat

Peittaus

Chamaenerion angustifolium

Regressiomuuttujat

Kylvöaika ............................... 1,298

Rikkaruoholaskennan päivä ............... $\quad 1,298$

Lohkon ikä peltona

Luokkamuuttujat

Peittaus

\section{Chenopodium album}

Regressiomuuttujat

Tilan peltoala

Typpilannoitus keväällä

Cirsium arvense

Regressiomuuttujat

Rikkaruohoruiskutusten määrä

Rikkaruoholaskennan päivä

Tilan peltoala

\section{Deschampsia caespitosa}

Regressiomuuttujat

Leikkuupuintien määrä

Karjanlannan määrä

Equisetum arvense

Regressiomuuttujat

Rikkaruoholaskennan päivä ...

Karjanlannan määrä

Equisetum silvaticum

Regressiomuuttujat

Rikkaruohoruiskutusten määrä .......... 1,298

Nurmien mäără

Luokkamuuttujat

Maalaji

Erysimum cheiranthoides

Regressiomuuttujat

Nurmien määrä

Lohkon ikä peltona

Luokkamuuttujat

Maalaji 
Fumaria officinalis

Regressiomuuttujat

Leikkuupuintien määrä $\ldots \ldots \ldots \ldots \ldots \ldots \ldots \ldots . . \ldots 1,295$

$10.76^{* *}$

Rikkaruoholaskennan päivä ................ $\quad 1,295$

$10.20 * *$

Tilan peltoala

Nurmien määrä

Typpilannoitus keväällä

Luokkamuuttujat

Maalaji

Galeopsis bifida

Regressiomuuttujat

Leikkuupuintien määrä

Tilan peltoala

Typpilannoitus keväällă

Luokkamuuttujat

Alue

Galeopsis speciosa

Regressiomuuttujat

Viljan peittávyys

Kvlvöaika

Tilan peltoala

Galeopsis spp.

Regressiomuuttujat

Viljan peittävyys

Rikkaruohoruiskutusten määrä

Kylvöaika

Lohkon etäisyys

Luokkamuuttujat

Maalaji

\section{Galium vaillantii}

Regressiomuuttujat

Viljan peittävyys

Leikkuupuintien määrä

Rikkaruohoruiskutusten määrä

Nurmien määrä

Luokkamuuttujat

Esikasvi

Gnaphalium uliginosum

Regressiomuuttujat

Kylvöaika ............................... 1,298

Rikkaruoholaskennan päivä

Luokkamuuttujat

Kosteus

Lapsana communis

Regressiomuuttujat

Lohkon ikä peltona 
Luokkamuuttujat

Esikasvi

Peittaus

Alue

Leontodon autumnalis

Regressiomuuttujat

Rikkaruohoruiskutusten määrä

Luokkamuuttujat

Alue

Matricaria spp.

Luokkamuuttujat

Maalaji

Esikasvi

Peittaus

Alue

Myosotis arvensis

Regressiomuuttujat

Typpilannoitus keväällä

Lohkon ikä peltona

Luokkamuuttujat

Maalaji

Esikasvi

Peittaus

Karjanlanta syksyllä ........................ $\quad 1,292$

Alue

Myosurus minimus

Regressiomuuttujat

Kylvöaika ................................. $\quad 1,300$

Lohkon ikä peltona

\section{Poa annua}

Luokkamuuttujat

Alue

Poa pratensis

Regressiomuuttujat

Leikkuupuintien määrä

Lohkon ikä peltona

Luokkamuuttujat

Esikasvi

Alue

\section{Poa trivialis}

Regressiomuuttujat

Viljan peittävyys

Nurmien määrä 
Luokkamuuttujat

Peittaus ..................................... 1,297

Alue ....................................... 1,297

$15.30 * * * \quad-$

$9.88 * *$

Polygonum aviculare

Regressiomuuttujat

Leikkuupuintien määrä

Polygonum convolvulus

Regressiomuuttujat

Rikkaruohoruiskutusten määrä ......... 1,298

Tilan peltoala

Typpilannoitus keväällä

Luokkamuuttujat

Alue

Polygonum lapathifolium

Regressiomuuttujat

Viljan peittävyys .......................... 1,296

Rikkaruoholaskennan päivä

Luokkamuuttujat

Maalaji ................................... 2,296

$7.58 * * * \quad-$

Kosteus

Ranunculus acris

Regressiomuuttujat

Leikkuupuintien määrä

Lohkon ikä peltona

Luokkamuuttujat

Peittaus

Karjanlanta syksyllä

Ranunculus auricomus

Luokkamuuttujat

Peittaus

Alue

\section{Ranunculus repens}

Regressiomuuttujat

Nurmien määrä

Luokkamuuttujat

Karjanlanta syksyllä

Alue

\section{Rumex acetosa}

Regressiomuuttujat

Rikkaruoholaskennan päivä

Luokkamuuttujat 
Rumex acetosella

Regressiomuuttujat

Lohkon ikä peltona

Luokkamuuttujat

Maalaji

Alue

Rumex longifolius

Regressiomuuttujat

Nurmien määrä

Sagina procumbens

Luokkamuuttujat

Alue

Sonchus arvensis

Regressiomuuttujat

Viljan peittävyys

Luokkamuuttujat

Alue

Spergula arvensis

Regressiomuuttujat

Kylvöaika

Rikkaruoholaskennan päivä

Luokkamuuttujat

Maalaji

Stellaria graminea

Regressiomuuttujat

Viljan peittävyys

\section{Stellaria media}

Regressiomuuttujat

Viljan peittävyys

Tilan peltoala

Lohkon ikä peltona

Luokkamuuttujat

Kosteus

Karjanlanta syksyllä

Taraxacum spp.

Regressiomuuttujat

Leikkuupuintien määrä .................... 1,292

Nurmien määrä

Typpilannoitus keväällä

Lohkon ikä peltona

Luokkamuuttujat

Maalaji

Esikasvi

Peittaus 


d.f. $\quad$ F

\section{Thlaspi arvense}

Regressiomuuttujat

Rikkaruoholaskennan päivä

$\begin{array}{ll}1,300 & 4.84^{*} \\ 1,300 & 5.45^{*}\end{array}$

Nurmien määrä

Trifolium repens

Regressiomuuttujat

Leikkuupuintien määrä

Rikkaruoholaskennan päivä

Karjalannan määrä

Typpilannoitus keväällä

Luokkamuuttujat

Maalaji

Veronica serpyllifolia

Regressiomuuttujat

Leikkuupuintien määrä

Nurmien määrä

Luokkamuuttujat

Alue

\section{Vicia cracca}

Regressiomuuttujat

Leikkuupuintien määrä

Rikkaruohoruiskutusten määrä ......... 1,299

Kylvöaika

Viola arvensis

Regressiomuuttujat

Viljan peittävyys

Lohkon ikä peltona

\section{Luokkamuuttujat}

Maalaji

3. 6. 2. Lohkon etäisyys talouskeskuksesta

Vain Galeopsis-suvun yksilöiden tiheyden todettiin olevan riippuvainen lohkon etäisyydestä talouskeskuksesta (taulukot 4 ja 6). Kyseessä lienee lähinnä G. bifida-laji. Lähes merkitsevä oli myös Polygonum lapathifoliumin tiheys. Kyseessä ovat melko niukkaravinteisten eloperäisten maiden lajit, ja eloperäiset maat sijaitsevat etäämmällä talouskeskuksista kuin kivennäismaat.

\section{6. 3. Lohkon ikä viljeltynä}

Lohkon iän todettiin vaikuttaneen 11 taksonin yksilötiheyteen (taulukot 4 ja 7). Näistä Chamaenerion angustifolium, Poa pratensis, Ranunculus acris, Rumex acetosella ja Stellaria media olivat nuorten viljelysten lajeja. Ne joko olivat lohkolla tai levisivät lohkolle ilmeisesti jo raivausvaiheessa, peruslannoituksena annetun karjanlannan mukana tai ensimmäisten kylvösiementen 
Taulukko 5. Tilan peltoalan vaikutus rikkaruohojen yksilö- tai versotiheyteen $\left(\mathrm{kpl} / \mathrm{m}^{2}\right)$ peltoalaltaan eri kokoisilla tiloilla.

Table 5. The plant or shoot density $\left(\mathrm{No} . / \mathrm{m}^{2}\right)$ of weeds on farms with different sizes of arable area.

Tilan peltoala, ha

Arable area of farm, ha

$\begin{array}{lll}-10 & 11-25 & 26-\end{array}$

Tilastollinen ero todettu -

Statistical difference

Chenopodium album s. lat.

41.9

Galeopsis spp.

6.9

26.8

15.6

Polygonum convolvulus

4.3

4.3

1.1

Stellaria media

15.3

4.0

3.9

Fumaria officinalis

0.7

10.7

6.2

Cirsium arvense

0.5

0.3

0.3

Galeopsis bifida

0.8

0.3

0.5

0.4

2.9

Ei tilastollista eroa -

No statistical difference

Agropyron repens $\quad 16.9$

Agrostis spp.

16.9
13.6

Erysimum cheiranthoides

12.2

Galeopsis spp.

39.7

Gnaphalium uliginosum

7.7

Lapsana communis

6.5

Matricaria spp.

Myosotis arvensis

5.9

9.7

Poa pratensis s. lat.

16.7

Polygonum aviculare s. lat.

8.0

P. lapathifolium

1.8

Ranunculus repens

9.2

Viola arvensis

29.4

12.9

20.6

9.4

45.3

6.8

6.2

8.2

5.9

11.1

6.6

4.7

8.7

28.8
9.5

9.4

8.0

34.8

8.2

3.7

13.0

7.7

2.7

6.5

8.9

10.8

26.1

mukana (Jokela 1971, M. RaAtikainen ja T. RaAtikainen 1972). Ensimmäisten rukiin kylvösiementen mukana levisi aikoinaan mm. Bromus secalinus ruispeltoihin. KAUHANEN (1975) totesi sen leviävän vielä 1970-luvullakin ilmeisesti tällä tavoin Iisalmen seudulla. Eräät varhain saapuneista lajeista kasvoivat aluksi tiheässä laikkuina, mutta uusien kilpailevien lajien levitessä lohkolle muuttuivat harvemmassa ja tasaisemmin kasvaviksi. Keski-ikäisten ja vanhojen viljelysten lajit olivat useimmiten vaikeasti muokkauksella tai tähän saakka käytössä olleilla herbisideillä torjuttavia lajeja.

\section{6. 4. Maalaji}

Maalaji oli yksi tärkeimmistä rikkakasvien tiheyteen vaikuttavista tekijöistä. Peräti 19 taksonin yksilötiheyteen sen todettiin vaikuttaneen merkitsevästi (taulukot 4 ja 8). Lajisto jakaantui selvästi kivennäismaiden ja eloperäisten maiden lajeihin. Edellisiä oli enemmän, ja niistä voitiin erottaa vielä pienehkö savimaiden lajiryhmä. Pari taksonia karttoi savimaita ja ne kuuluivat lähinnä karkeiden kivennäismaiden ja eloperäisten maiden lajeihin. 


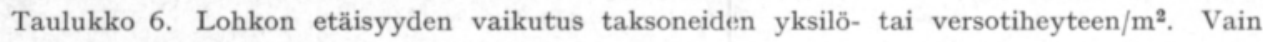
Galeopsis-suvun yksilöiden yksilötiheysero merkitsevä.

Table 6. Influence of the distance of field on the plant or shoot density $/ m^{2}$ of the taxa. The difference is significant only in the plant densities of Galeopsis spp.

\begin{tabular}{|c|c|c|c|}
\hline & \multicolumn{3}{|c|}{$\begin{array}{l}\text { Lohkon etäisyys talouskeskuksesta, } \mathrm{km} \\
\text { Distance of field from farmstead, } \mathrm{km}\end{array}$} \\
\hline & $<0.2$ & $0.2-0.7$ & $>0.7$ \\
\hline Galeopsis spp. & 34.3 & 43.7 & 45.5 \\
\hline Agropyron repens & 19.0 & 7.5 & 12.0 \\
\hline Agrostis spp. & 13.5 & 19.7 & 12.6 \\
\hline Chenopodium album s. lat. & 38.2 & 18.9 & 24.0 \\
\hline Erysimum cheiranthoides & 9.6 & 8.5 & 11.4 \\
\hline Gnaphalium uliginosum & 6.2 & 10.1 & 5.6 \\
\hline Lapsana communis & 5.6 & 6.0 & 4.9 \\
\hline Matricaria spp. & 9.4 & 9.2 & 8.3 \\
\hline Myosotis arvensis & 9.5 & 8.9 & 2.5 \\
\hline Poa pratensis s. lat. & 9.8 & 14.4 & 4.7 \\
\hline Polygonum aviculare s. lat. & 7.8 & 6.7 & 6.0 \\
\hline P. lapathifolium & 2.3 & 4.1 & 10.4 \\
\hline Ranunculus repens & 7.4 & 14.0 & 6.1 \\
\hline Stellaria media & 11.5 & 9.3 & 10.9 \\
\hline Viola arvensis & 25.8 & 33.4 & 24.4 \\
\hline
\end{tabular}

Tulokset olivat Myosotis arvensis, Fumaria officinalis, Polygonum lapathifolium ja Spergula arvensis -lajien osalta samanlaiset kuin kevätviljoissa (vrt. MUKULA et al. 1969) ja Achillea millefolium, Myosotis arvensis, Taraxacum spp., Trifolium repens ja Rumex acetosa -taksonien osalta samanlaiset kuin heinänurmissa (vrt. M. Raatikainen ja T. RaAtikainen 1975). Lisäksi Agropyron repens ja Agrostis spp. (A. tenuis) -lajien tulokset olivat lähes samanlaiset. Muidenkaan lajien osalta tulokset eivät ole aikaisempien tulosten kanssa ristiriitaisia. Muutamia taulukossa 4 mainittuja lajeja ei ole aikaisemmin todettu selvästi minkään maalajin kasviksi. Tulokset vahvistavat aikaisemmin saatuja paikallisia tuloksia tai tuovat niihin olennaisia lisätietoja (vrt. JALAS ja JUUSELA 1959, M. Raatikainen ja T. Raatikainen 1964, Poranen 1972, Kauhanen 1975).

3. 6. 5. Maaperän kosteus

Maaperän kosteuden todettiin merkitsevästi vaikuttaneen vain viiden lajin yksilötiheyteen (taulukot 4 ja 9). Nämä olivat lajeja, joihin maaperän kosteuden on todettu jo muissakin tutkimuksissa vaikuttaneen samantapaisesti (Jalas ja Juusela 1959, Mukula et al. 1969, M. RaAtikainen ja T. RaATIKAINEN 1975). Lajeista, joihin maaperän kosteuden ei todettu selvästi vaikuttaneen, on aikaisemmin Viola arvensiksen todettu suosivan kuivia kasvupaikkoja (MukUla et al. 1969) ja Ranunculus repensin kosteita kasvupaikkoja (M. RaAtikainen ja T. RaAtikainen 1975). Tämänkin tutkimuksen aineisto tukee näitä tuloksia. 
Taulukko 7. Lohkon peltonaoloiän vaikutus rikkaruohojen yksilö- tai versotiheyteen $\left(\mathrm{kpl} / \mathrm{m}^{2}\right)$. Table 7. Influence of the age of cultivated field on weed plant or shoot density $\left(\mathrm{No} . / \mathrm{m}^{2}\right)$.

\begin{tabular}{|c|c|c|c|c|c|}
\hline & \multicolumn{5}{|c|}{$\begin{array}{c}\text { Lohkon ikä vuotta ja lohkojen lukumäärä } \\
\text { Age of field, years and number of fields }\end{array}$} \\
\hline & $0-29$ & $30-59$ & $60-89$ & $90-119$ & $120-$ \\
\hline \multicolumn{6}{|l|}{ Tilastollinen ero todettu } \\
\hline \multicolumn{6}{|l|}{ Statistical difference } \\
\hline Chamaenerion angustifolium & 2.9 & 0.3 & 0.5 & 0.2 & 0.1 \\
\hline Poa pratensis s. lat. & 26.3 & 12.1 & 8.0 & 6.1 & 4.3 \\
\hline Ranunculus acris s. lat. & 2.8 & 1.0 & 0.1 & 0.5 & 0.1 \\
\hline Stellaria media & 29.6 & 10.3 & 3.8 & 8.6 & 5.3 \\
\hline Rumex acetosella s. lat. & 8.6 & 2.0 & 6.9 & 0.6 & 1.2 \\
\hline Taraxacum spp. & 2.1 & 1.8 & 1.5 & 4.1 & 3.0 \\
\hline Agropyron repens & 8.0 & 12.2 & 10.3 & 15.7 & 13.4 \\
\hline Erysimum cheiranthoides & 4.5 & 11.6 & 6.2 & 12.2 & 7.5 \\
\hline Myosurus minimus & 0.5 & 3.5 & 2.3 & 4.2 & 2.6 \\
\hline Viola arvensis & 5.3 & 30.1 & 38.1 & 32.3 & 26.3 \\
\hline Lapsana communis & 0.7 & 8.7 & 2.9 & 4.5 & 8.0 \\
\hline Myosotis arvensis & 3.4 & 7.1 & 9.7 & 7.4 & 9.0 \\
\hline \multicolumn{6}{|l|}{ Ei tilastollista eroa } \\
\hline \multicolumn{6}{|l|}{ No statistical difference } \\
\hline Agrostis spp. & 31.4 & 10.7 & 24.3 & 7.2 & 23.4 \\
\hline Chenopdium album s. lat. & 24.3 & 23.6 & 9.3 & 41.8 & 17.1 \\
\hline Galeopsis spp. & 19.0 & 45.7 & 50.3 & 46.8 & 29.6 \\
\hline Gnaphalium uliginosum & 17.9 & 4.0 & 7.3 & 9.5 & 1.3 \\
\hline Matricaria spp. & 9.2 & 8.9 & 65 & 10.1 & 8.7 \\
\hline Polygonum aviculare s. lat. & 3.9 & 6.9 & 8.9 & 8.0 & 5.4 \\
\hline P. lapathifolium & 7.5 & 3.0 & 6.5 & 6.7 & 3.0 \\
\hline Ranuculus repens & 20.4 & 8.1 & 3.7 & 11.1 & 3.7 \\
\hline
\end{tabular}

\section{6. 6. Leikkuupuintikertojen määrä}

Leikkuupuinti on viime vuosikymmeninä alkanut merkittävästi vaikuttaa rikkaruoholajien yksilötiheyteen (Petzolt 1959, Aamisepp et al. 1967, Mukula et al. 1969). Tämän tutkimuksen mukaan leikkuupuintikertojen määrä 10 ruisvaihetta edeltävän vuoden aikana on vaikuttanut merkitsevästi 12 taksonin yksilötiheyteen (taulukot 4 ja 10). Tämä on kuitenkin osittain näennäistä, sillä useimmat lajit ovat tyypillisiä nurmikasveja, joiden kasvupaikoilla ei nurmivaiheen takia ole käytetty leikkuupuimuria. Nekin lajit, jotka näyttävät runsastuneen leikkuupuinnin käytön takia, lienevät useimmiten lajeja, jotka ovat runsastuneet sen takia, että lohkolla on aikaisemmin viljelty viljoja, joissa nämä lajit ovat runsastuneet muista syistä kuin leikkuupuinnin takia. Todellisuudessa siis vain hyvin harvat lajit ovat päässeet runsastumaan leikkuupuinnin takia. Lajimäärä olisi kuitenkin suurempi, jos leikkuupuinnin käyttöön ei liittyisi herbisidien käyttöä, joka vastaavasti alensi leikkuupuinnissa runsastuneiden lajien yksilötiheyttä.

\section{6. 7. Herbisidikäsittelyjen määrä}

Pitkäaikainen herbisidien käyttö on muuttanut suuresti peltojen rikkakasvikoostumusta sekä Suomessa (Mukula et al. 1969) että muissa maissa 
Taulukko 8. Rikkaruohojen yksilö- tai versomäärä/ $\mathrm{m}^{2}$ eri maalajeilla.

Table 8. Number of weed plants or shoots $/ \mathrm{m}^{2}$ on different soil types.

\begin{tabular}{lll}
$\begin{array}{l}\text { Karkeat kivennäis- } \\
\text { maat ja hiesut } \\
\text { Coarse mineral } \\
\text { soils and silts }\end{array}$ & Savimaat & Eloperäiset mat \\
\hline
\end{tabular}

Karkeiden kivennäismaiden ja

eloperäisten maiden lajit

Species of coarse mineral

soils and organic soils

Agropyron repens

18.2

5.8

11.5

Agrostis spp.

20.1

2.4

32.6

Kivennäismaiden lajit

Species of mineral soils

Achillea millefolium

5.0

2.5

0.5

Capsella bursa-pastoris

2.8

2.6

0.4

Centaurea cyanus

0.9

1.0

0.0

Erysimum cheiranthoides

8.5

13.2

4.9

Myosotis arvensis

9.0

6.6

3.1

Taraxacum spp.

3.6

2.6

0.3

Trifolium repens

3.2

1.7

1.3

Viola arvensis

28.4

29.4

24.2

Savimaiden lajit

Species of clay soils

Equisetum silvaticum

0.3

0.5

0.0

Fumaria officinalis

0.3

0.8

0.1

Matricaria spp.

7.2

11.8

8.7

Eloperäisten maiden lajit

Species of organic soils

Alopecurus geniculatus

0.1

0.0

1.2

Galeopsis spp.

Polygonum lapathifolium

Rumex acetosa s. lat.

0.4

0.1

1.0

3.3

0.4

6.5

Spergula arvensis

6.9

1.0

7.4

Muita lajeja

Other species

Chenopodium album s. lat.

Poa pratensis s. lat.

Polygonum aviculare s. lat.

(esim. Schubert et al. 1975). Rukiissakin 9 taksonin yksilötiheyden todettiin riippuvan herbisidien käyttökerroista 10 viime vuoden aikana (taulukot 4 ja 11). Näistä ruiskutuksiin yleisimmin käytetyle MCPA:.lle herkät lajit Cirsium arvense, Equisetum silvaticum, Galeopsis spp. ja Vicia cracca sekä kohtalaisen herkät lajit Achillea ptarmica ja Leontodon autumnalis olivat niukentuneet ja 
Taulukko 9. Kasvualustan kosteuden vaikutus rikkaruohojen yksilö- tai versomäärään $/ \mathrm{m}^{2}$. Table 9. Influence of moisture conditions of soil on the number of weed plants or shoots $/ \mathrm{m}^{2}$.

\begin{tabular}{|c|c|c|c|}
\hline & $\begin{array}{c}\text { Poutiva } \\
\text { Dry }\end{array}$ & $\begin{array}{l}\text { Kasvualustan kost } \\
\text { Ioisture conditions } \\
\text { Keskinkertainen } \\
\text { Medium dry }\end{array}$ & $\begin{array}{l}\text { soil } \\
\text { Veden vaivaama } \\
\qquad \text { Wet }\end{array}$ \\
\hline Poutivan maan lajit & & & \\
\hline Species of dry soil & & & \\
\hline Rumex acetosa s. lat. & 0.8 & 0.3 & 0.3 \\
\hline $\begin{array}{l}\text { Poutivan ja keskinkertaisen } \\
\text { kostean maan lajit } \\
\text { Species of dry and medium } \\
\text { dry soil }\end{array}$ & & & \\
\hline Agropyron repens & 13.3 & 13.7 & 2.9 \\
\hline $\begin{array}{l}\text { Kosteahkon maan lajit } \\
\text { Species of wet soil }\end{array}$ & & & \\
\hline Stellaria media & 6.0 & + $\quad 11.5$ & 8.3 \\
\hline Gnaphalium uliginosum & 4.9 & 7.8 & 8.7 \\
\hline Polygonum lapathifolium & 2.1 & 5.5 & 7.7 \\
\hline $\begin{array}{l}\text { Muita lajeja } \\
\text { Other species }\end{array}$ & & & \\
\hline Agrostis spp. & 7.4 & 15.3 & 35.6 \\
\hline Chenopodium album s, lat. & 59.6 & 20.0 & 43.9 \\
\hline Erysimum cheiranthoides & 16.8 & 8.7 & 5.7 \\
\hline Galeopsis spp. & 39.0 & 40.7 & 45.7 \\
\hline Lapsana communis & 4.7 & 6.1 & 0.8 \\
\hline Matricaria spp. & 16.9 & 8.0 & 4.6 \\
\hline Myosotis arvensis & 10.3 & 7.3 & 1.5 \\
\hline Poa pratensis s. lat. & 8.7 & 10.8 & 4.2 \\
\hline Polygonum aviculare s. lat. & 9.8 & 6.4 & 7.2 \\
\hline Ranunculus repens & 6.3 & 10.1 & 8.5 \\
\hline Viola arvensis & 31.7 & 28.3 & 18.9 \\
\hline
\end{tabular}

MCPA:ta kestävät Agropyron repens ja Galium vaillantii sekä kohtalaisen kestävä Polygonum convolvulus runsastuneet. Monivuotisten nurmirikkaruohojen osalta niukentuminen oli kuitenkin suureksi osaksi näennäistä ja aiheutui nurmivaiheen puuttumisesta tai niukasta esiintymisestä usein ruiskutetuilla lohkoilla. MUKULA et al. (1969) ovat jo aikaisemmin todenneet Galeopsis spp.:n Chenopodium albumin ja Erysimum cheiranthoideksen niukentuneen kevätviljapelloissa. Tämänkin tutkimuksen aineisto osoittaa kahden viimeksi mainitun niukentuneen, mutta tulokset eivät kuitenkaan ole tilastollisesti merkitseviä. Samassa tutkimuksessa on todettu myös Agropyron repensin ja Galium vaillantiin runsastuneen.

3. 6. 8. Esikasvi

Esikasvilla on vaikutusta siihen, mitkä rikkakaะvit ovai viljapelloilla runsaita (mm. Mukula et al. 1969, Kauhanen 1975). Tässä tutkimuksessa todettiin seitsemän taksonin runsaudessa syysviljojen esikasvista johtuvia 
Taulukko 10. Kymmenen viime vuoden aikana lohkolla suoritettujen leikkuupuintikertojen määrän vaikutus rikkaruohojen yksilö- tai versomäärään/ $\mathrm{m}^{2}$.

Table 10. Influence of combine harvesting during the last ten years on the number of weed plants or shoots $/ \mathrm{m}^{2}$.

Leikkuupuintikerrat

Numbsr of combine harvestings

$\begin{array}{llll}0 & 1-3 & 4-6 & 7-\end{array}$

Tilastollinen ero todettu

Statistical difference

Cerastium caespitosum

Deschampsia caespitosa

Poa pratensis s. lat.

Ranunculus acris s. lat.

Taraxacum spp.

Trifolium repens

Veronica serpyllifolia

Galium vaillantii

Galeopsis bifida

Polygonum aviculare s. lat.

Vicia cracca

Fumaria officinalis

$\begin{array}{rrrr}6.0 & 3.0 & 3.3 & 0.4 \\ 3.2 & 0.4 & 0.1 & 0.1 \\ 24.9 & 13.9 & 3.9 & 1.4 \\ 1.6 & 1.5 & 0.2 & 0.0 \\ 7.7 & 2.2 & 2.0 & 0.6 \\ 5.0 & 2.3 & 2.5 & 0.5 \\ 8.0 & 6.3 & 4.3 & 0.3 \\ 0.4 & 0.3 & 0.2 & 0.3 \\ 0.1 & 1.7 & 2.7 & 0.2 \\ 5.1 & 8.2 & 6.4 & 7.4 \\ 0.1 & 0.1 & 0.1 & 0.1 \\ 0.2 & 0.4 & 0.5 & 0.6\end{array}$

Ei tilastollista eroa

No statistical difference

Agropyron repens

12.1

17.9

13.6

7.9

Agrostis spp.

16.1

25.9

15.8

4.5

Chenopodium album s. lat.

35.2

26.9

21.6

27.3

Erysimum cheiranthoides

4.9

10.4

11.9

10.3

Galeopsis spp.

48.8

52.4

30.3

33.4

Gnaphalium uliginosum

8.3

6.9

9.8

5.3

Lapsana communis

$\begin{array}{ll}6.1 & 5.4\end{array}$

6.8

4.2

Matricaria spp.

3.2

8.4

13.1

Myosotis arvensis

$\begin{array}{ll}6.6 & 10.3\end{array}$

9.7

4.4

Polygonum lapathifolium

$2.9 \quad 11.3$

7.9

1.2

Ranunculus repens

11.4

4.7

11.7

10.0

12.2

3.4

15.9

12.0

5.9

Viola arvensis

29.9

31.6

25.1

26.4

eroja (taulukot 4 ja 12). Yksivuotisten viljelykasvien jälkeen olivat runsaimpia yksivuotiset tai syysyksivuotiset rikkaruohot, syysviljojen jälkeen syysyksivuotiset ja nurmen jälkeen monivuotiset, nurmissa kylvämättä kasvavat lajit.

Tutkimuksessa tarkasteltiin myös esikasvia edeltäneiden 2.-4. vuoden viljelykasvien - varsinkin nurmien - vaikutusta syysviljojen rikkaruoholajistoon. Tällöin todettiin, että mitä useampana vuonna lohkolla oli viljelty nurmikasveja sitä tiheämmässä siinä kasvoi syysviljavaiheessa etenkin monivuotisia nurmien rikkaruohoja, mutta myös eräitä avoviljelysten lajeja (taulukot 4 ja 13). Pitkäaikaisesta nurmellaolovaiheesta kärsivät eräät yksivuotiset kasvilajit (vrt. Munula et al. 1969, M. RaAtikainen ja T. RaAtikainen 1975) sekä mahdollisesti myös kyntöä kestävä avoviljelysten melko tyypillinen monivuotinen rikkaruoho Equisetum silvaticum (taulukot 4 ja 13). 
Taulukko 11. Kymmenen viime vuoden aikana tehtyjen rikkaruohoruiskutuskertojen määrän vaikutus rikkaruohojen yksilö- tai versomäärään $/ \mathrm{m}^{2}$.

Table 11. Influence of the number of herbicidal treatments on the number of weed plants or shoots $/ \mathrm{m}^{2}$

Ruiskutuskertoja

Number of herbicidal treatments

$\begin{array}{llll}0 & 1-3 & 4-6 & 6\end{array}$

Tilastollinen ero todettu

Statistical difference

Achillea ptarmica

Equisetum silvaticum

2.7

1.0

0.9

0.7

0.1

Galeopsis spp.

56.5

Leontodon autumnalis

0.7

0.0

0.1

0.0

Vicia cracca

0.2

42.8

32.5

23.5

Cirsium arvense

0.5

0.2

0.0

Agropyron repens

6.9

Galium vaillantii

0.1

Polygonum convolvulus

1.7

0.1

0.2

0.1

0.0

0.6

0.2

0.3

19.5

16.0

9.7

0.4

0.2

0.5

Ei tilastollista eroa

No statistical difference

Agrostis spp.

17.2

5.4

4.3

5.4

Chenopodium album s. lat.

30.3

22.7

15.1

3.7

Erysimum cheiranthoides

8.2

38.8

18.7

17.0

Gnaphalium uliginosum

7.8

14.3

8.6

7.1

Lapsana communis

7.1

8.5

6.3

3.4

7.7

5.5

8.8

6.9

14.4

Myosotis arvensis

10.2

Poa pratensis s. lat.

8.9

5.1

18.3

11.5

0.3

4.8

10.0

Polygonum aviculare s. lat.

8.9

P. lapathifolium

Ranunculus repens

14.6

5.6

5.8

6.1

Stellaria media

12.1

8.2

6.8

0.6

3.7

0.3

Viola arvensis

25.6

13.4

11.9

6.5

36.2

8.5

26.3

\section{6. 9. Karjanlanta}

Karjanlannan mukana kulkeutuu monien rikkaruohojen siemeniä (mm. Korsmo 1935), ja Suomessakin todettiin 1960-luvulla eräiden rikkaruohojen tiheyden olevan suurimman karjanlantaa saaneilla kevätviljapelloilla (MUKULA et al. 1969). Tämänkin tutkimuksen mukaan eräiden lajien yksilötiheys oli suurin karjanlantaa saaneilla lohkoilla (taulukot 4 ja 14). Tuloksiin täytyy kuitenkin suhtautua varauksella, sillä $\mathrm{mm}$. Myosotis arvensis, Ranunculus repens, ehkä myös $R$. acris ovat lajeja, joiden yksilötiheys oli suurin VäliSuomen kivennäismailla, joita useimmin lannoitettiin karjanlannalla; täten muut seikat saattoivat olla todellisia syitä.

\section{6. 10. Kylvöaika}

Muokkaus vaikuttaa edistävästi monien rikkaruohojen itämiseen. Kylvömuokkauksella ja sen jälkeisillä säillä on usein yhdessä ratkaiseva merkitys rikkaruohottumiseen. Tämän tutkimuksen mukaan kylvöaika vaikutti useiden kasvien yksilötiheyteen. Joidenkin tiheys oli suurin aikaisten, joidenkin myö- 
Taulukko 12. Esikasvin vaikutus rikkaruohojen yksilö- tai versomäärään $/ \mathrm{m}^{2}$.

Table 12. Influence of the previous crop on the number of weed plants or shoots $/ \mathrm{m}^{2}$.

\begin{tabular}{ccccc}
\hline & \multicolumn{4}{c}{ Esikasvit - Previous crop } \\
\cline { 2 - 5 } & Kevätvilja & Syysvilja & Nurmi & Mut \\
Spring cereal & Winter cereal & Ley & Others \\
\hline
\end{tabular}

Kevät- ja syysviljan 'jälkeen tiheimmässä - Highest density atter sping and winter cereal
Lapsana communis
9.6
6.0
3.4
3.9

Syysviljan jälkeen tiheimmässä - Highest density after winter cereal

\begin{tabular}{|c|c|c|c|c|}
\hline Galium vaillantii & 0.3 & 0.6 & 0.0 & 0.4 \\
\hline Matricaria spp. & 10.2 & 14.8 & 4.2 & 10.9 \\
\hline
\end{tabular}

Viljojen ja nurmen jälkeen tiheimmässä - Highest density after cereals and ley
Myosotis arvensis
4.3
7.0
11.6

Nurmen jälkeen tiheimmässä - Highest density after ley

$\begin{array}{lrrrr}\text { Poa pratensis s. lat. } & 0.6 & 1.4 & 23.5 & 4.5 \\ \text { Taraxacum spp. } & 0.2 & 0.6 & 6.5 & 0.8\end{array}$

Muiden viljelykasvien jälkeen tiheimmessä -- Highest ciensity after other crops
Alopecurus geniculatus
0.2
0.1
0.0
1.0

Tiheyseroja ei todettu - No differences in densities

\begin{tabular}{lrrrr} 
Agropyron repens & 12.6 & 9.0 & 19.3 & 3.5 \\
Agrostis spp. & 4.4 & 7.7 & 27.8 & 13.8 \\
Chenopodium album s. lat. & 38.9 & 26.0 & 23.5 & 20.2 \\
Erysimum cheiranthoides & 10.3 & 12.8 & 9.4 & 5.6 \\
Galeopsis spp. & 29.8 & 4.0 .7 & 47.1 & 42.8 \\
Gnaphalium uliginosum & 9.4 & 4.9 & 8.0 & 6.8 \\
Polygonum aviculare s. lat. & 5.3 & 9.0 & 6.0 & 8.7 \\
P. lapahtifolium & 3.1 & 1.6 & 19.6 & 14.2 \\
Ranunculus repens & 4.9 & 1.4 & 11.5 & 3.4 \\
Stellaria media & 11.7 & 10.6 & 30.7 & 19.3 \\
Viola arvensis & 30.2 & 28.2 & & \\
\hline
\end{tabular}

häisten kylvöjen jälkeen (taulukot 4 ja 15). Viimeksi mainitut olivat yleensä kevätyksivuotisia kasveja, joiden itämiseen ja orastumiseen myöhäinen kylvö ja maan pintakerroksen kuohkeus saattoivat vaikuttaa seuraavana keväänä edullisesti. Lisäksi kilpailu viljan kanssa oli ilmeisesti vähäisempi kuin aikaisin kylvetyillä lohkoilla. Syysyksivuotiset saattoivat hyötyä varhaisesta kylvöstä; ne ehtivät kasvaa sopivaan talvehtimisvaiheeseen. Oletukset kaipaavat kokeellista varmennusta.

\section{6. 11. Peittaus}

Peittaus saattaisi edistää eräiden rikkakasvilajien talvehtimista (taulukot 4 ja 16), mutta kyseessä saattoivat olla kuitenkin useimmiten muut tekijät, jotka olivat näille lajeille edullisia juuri niillä lohkoilla, joille peittausaineilla käsiteltyjä siemeniäkin kylvettiin. 
Taulukko 13. Lohkon nurmenaolovuosien määrän vaikutus rikkaruohojen yksilö- tai versotiheyteen $/ \mathrm{m}^{2}$. Nurmenaolovuosien määrä laskettu kolmelta esikasvia edeltävältä vuodelta. Table 13. Influence of the age of ley on weed plant or shoot density $/ \mathrm{m}^{2}$. The age of ley is counted from three years precending the previous crop.

\begin{tabular}{lllll}
\hline & \multicolumn{3}{l}{$\begin{array}{l}\text { Nurmenaolovuosien määrä } \\
\text { Age of ley, years }\end{array}$} \\
\cline { 2 - 5 } & 0 & 1 & 2 & 3 \\
\hline
\end{tabular}

Tilastollinen ero todettu

Statistical difference

Galium vaillantii

Equisetum silvaticum

0.6

0.6

0.1

0.2

0.1

Erysimum cheiranthoides

9.4

0.0

0.3

Fumaria officinalis

0.4

6.0

0.2

11.1

Ranunculus repens

3.2

0.1

10.6

0.8

Poa trivialis

1.0

0.7

0.3

15.1

Centaurea cyanus

0.2

0.3

17.6

8.6

Thlaspi arvense

0.5

1.1

4.6

0.5

1.7

Agropyron repens

1.8

2.3

2.0

4.6

16.4

16.5

19.2

Cerastium caespitosum

1.1

2.1

3.7

5.2

0.5

0.5

Veronica serpyllifolia

1.8

2.7

Rumex longifolius

0.0

0.0

3.9

5.9

6.0

0.0

7.8

0.7

Ei tilastollista eroa

No statistical difference

Agrostis spp.

Chenopodium album s. lat.

7.9

27.2

Galeopsis spp.

Gnaphalium uliginosum

Lapsana communis

Matricaria spp.

Myosotis arvensis

Poa pratensis s. lat.

Polygonum aviculare s. lat.

P. lapathifolium

Stellaria media

Viola arvensis
28.0

4.4

6.1

11.7

5.3

2.2

7.5

1.8

9.0

24.4
8.6

17.7

31.2

4.0

3.9

9.3

8.2

2.9

5.7

2.8

9.6

29.0
37.8

18.1

45.3

15.2

4.8

7.7

7.0

15.3

6.4

5.7

12.3

33.5
9.0

41.0

59.4

6.3

6.4

6.4

10.1

19.7

7.1

10.6

11.4

28.1

\section{6. 12. Kevätlannoitus}

Keväällä annettu typpilannoitus vaikutti etenkin yksivuotisten rikkaruohojen kasvuun, mutta monivuotisten versotiheyttä se ei kohottanut. Niiden lukumäärä oli alentunut (taulukot 4 ja 17). Tämä lienee kuitenkin virheellinen tulos ja selittynee mm. näitä kasveja kasvavien lohkojen harvinaisemmasta kevätlannoittamisesta.

\section{6. 13. Rikkaruohoruiskutus}

Rikkaruohoruiskutusten vaikutusta rikkakasveihin selvitettiin kaikilla ruiskutetuilla lohkoilla, mutta koska aineisto on melko laaja sen antamat tulokset julkistetaan myöhemmin erillisenä osatutkimuksena. 
Taulukko 14. Rikkaruohojen yksilö- tai versomäärä $/ \mathrm{m}^{2}$ karjanlannalla syksyllä lannoittamattomilla ja lannoitetuilla lohkoilla.

Table 14. Number of weed plants or shoots $/ m^{2}$ on fields without farmyard manure and with farmyard manure in autumn.

\begin{tabular}{|c|c|c|}
\hline & $\begin{array}{l}\text { Lannoittamaton } \\
\text { Not manured }\end{array}$ & $\begin{array}{c}\text { Lannoitettu } \\
\text { Manured }\end{array}$ \\
\hline \multicolumn{3}{|l|}{ Tilastollinen ero todettu } \\
\hline \multicolumn{3}{|l|}{ Statistical differences } \\
\hline Alopecurus geniculatus & 0.1 & 0.4 \\
\hline Capsella bursa-pastoris & 1.7 & 4.0 \\
\hline Equisetum arvense & 1.0 & 3.7 \\
\hline Myosotis arvensis & 5.2 & 12.3 \\
\hline Ranunculus acris s. lat. & 0.4 & 1.6 \\
\hline$R$. repens & 8.5 & 11.4 \\
\hline Stellaria media & 10.7 & 10.0 \\
\hline \multicolumn{3}{|l|}{ Ei tilastollista eroa } \\
\hline \multicolumn{3}{|l|}{ No statistical difference } \\
\hline Agropyron repens & 12.1 & 14.6 \\
\hline Agrostis spp. & 13.9 & 19.1 \\
\hline Chenopodium album s. lat. & 28.1 & 25.4 \\
\hline Erysimum cheirathoides & 10.7 & 7.4 \\
\hline Galeopsis spp. & 39.6 & 43.5 \\
\hline Gnaphalium uliginosum & 7.1 & 8.2 \\
\hline Lapsana communis & 6.0 & 4.5 \\
\hline Matricaria spp. & 10.1 & 6.6 \\
\hline Poa pratensis s. lat. & 8.0 & 14.7 \\
\hline Polygonum aviculare s. lat. & 6.7 & 7.4 \\
\hline P. lapathifolium & 5.9 & 3.6 \\
\hline Viola arvensis & 25.7 & 33.7 \\
\hline
\end{tabular}

3. 6. 14. Rikkaruoholajien yksilötiheys tutkimuskauden eri aikoina

Syysviljojen rikkakasveista suurin osa taimettuu keväällä, mutta osa jo syksyllä. Itämiseen vaikuttavat monet ulkoiset syyt, mm. maaperän kosteus ja lämpötila, ja taimettumiseen mm. maanpinnan kuorettuminen. Syysitoisten kasvien yksilötiheydessä ei Thlaspi arvensea lukuun ottamatta havaittu selviä muutoksia kesäkuun alkupuoliskon aikana, mikä todistaa, että niiden siemenet olivat lähes kokonaan itäneet ennen tutkimusaikaa ja kilpailukykyiset yksilöt eivät yleensä kuolleetkaan tutkimuskautena. Useiden kevätyksivuotisten lajien yksilötiheys sen sijaan suurentui kesäkuun alkupuolella (taulukot 4 ja 18), mikä osoittaa näiden lajien taimettumiskauden jatkuneen vielä näinkin myöhään. Kyseessä olivat kuitenkin yksilöt, jotka eivät kyenneet menestyksellisesti kilpailemaan viljakasvuston kanssa, vaikka jäivätkin toukokuussa tehdyn herbisidiruiskutuskauden jälkeen itäneinä kasvamaan. Rumex acetosa ja Trifolium repens olivat monivuotisia varjostusta kestäviä lajeja, mutta nekin tuhoutuivat yleensä syysmuokkauksessa. Kun syysviljaa käytettiinnurmen suojakasvina, säilyivät nämä lajit ja olivat seuraavana vuonna heinänurmissa haittakasveina. Chamaenerion angustifoliumin versot tulivat näkyviin myöhään. Monivuotisten Cirsium arvensen ja Equisetum arvensen verso- 
Taulukko 15. Rukiin kylvöpäivän vaikutus rikkaruohojen yksilö- tai versotiheyteen $/ \mathrm{m}^{2}$. Table 15. Influence of sowing date of rye on weed plant or shoot density/ $/ m^{2}$.

\begin{tabular}{|c|c|c|c|c|}
\hline \multirow[t]{2}{*}{ 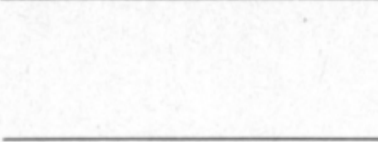 } & \multicolumn{4}{|c|}{$\begin{array}{l}\text { Kylvöpäivämäärä elo-syyskuussa } \\
\text { Sowing date in August-September }\end{array}$} \\
\hline & 1. -18 . & 19. -23 . & $24 .-28$ & 29.- \\
\hline \multicolumn{5}{|l|}{ Tilastollinen ero todettu } \\
\hline \multicolumn{5}{|l|}{ Statistical difference } \\
\hline Chamaenerion angustifolium & 1.4 & 0.7 & 0.6 & 0.1 \\
\hline Galeopsis spp. & 37.6 & 49.8 & 41.7 & 32.2 \\
\hline Spergula arvensis & 1.7 & 8.9 & 4.8 & 2.3 \\
\hline Agropyron repens & 7.5 & 9.9 & 16.6 & 13.5 \\
\hline Galeopsis speciosa & 0.2 & 1.5 & 7.5 & 3.7 \\
\hline Gnaphalium uliginosum & 3.4 & 5.1 & 9.7 & 8.9 \\
\hline Vicia cracca & 0.1 & 0.1 & 0.1 & 0.1 \\
\hline Myosurus minimus & 2.1 & 2.0 & 2.4 & 5.7 \\
\hline \multicolumn{5}{|l|}{ Ei tilastollista eroa } \\
\hline \multicolumn{5}{|l|}{ No statistical difference } \\
\hline Agrostis spp. & 13.3 & 25.2 & 11.0 & 12.8 \\
\hline Chenopodium album s. lat. & 23.0 & 37.0 & 22.9 & 25.6 \\
\hline Erysimum cheiranthoides & 6.1 & 10.7 & 12.4 & 6.8 \\
\hline Lapsana communis & 2.9 & 4.6 & 7.7 & 5.0 \\
\hline Matricaria spp. & 9.2 & 8.6 & 9.7 & 8.5 \\
\hline Myosotis arvensis & 12.4 & 10.0 & 5.9 & 4.2 \\
\hline Poa pratensis s. lat. & 22.5 & 7.8 & 10.4 & 5.8 \\
\hline Polygonum aviculare s. lat. & 9.8 & 6.4 & 5.6 & 7.8 \\
\hline P. lapathifolium & 3.6 & 4.0 & 9.2 & 1.8 \\
\hline Ranunculus repens & 26.2 & 7.8 & 8.6 & 4.1 \\
\hline Stellaria media & 4.2 & 13.5 & 9.7 & 11.6 \\
\hline Viola arvensis & 24.5 & 34.5 & 30.2 & 20.9 \\
\hline
\end{tabular}

tiheyksien todettiin alentuneen kesäkuun loppupuoliskolla. Tätä on vaikea selittää; syynä saattavat olla ainakin osaksi muut tekijät tai sattuma.

\section{6. 15. Viljan peittävyys}

Viljan ja rikkakasvien väliseen kilpailuun on kiinnitetty huomiota lukuisissa tutkimuksissa (mm. ERvıö 1973). Tämän tutkimuksen suoritusajankohtana rukiin peittävyys oli vielä alhainen ja kilpailu rikkakasvien kanssa vähäistä. Kilpailun alkutilanne oli kuitenkin jo selvästi nähtävissä, ja eräiden kevätitoisten lajien, kuten Polygonum lapathifoliumin ja Galeopsis bifidan yksilötiheydet alkoivat alentua ruiskasvustojen biomassan suurentuessa (taulukot 4 ja 19). Hyvin monen kasvilajin tiheys oli kuitenkin suurempi tiheissä ruiskasvustoissa kuin harvoissa. Nämä lajit olivat yleensä syysyksivuotisia tai monivuotisia. Syysyksivuotisesta Stellaria mediasta on julkaisemattomissa kokeissamme ilmennyt, että sen syksyllä itäneet yksilöt talvehtivat sitä paremmin, mitä tiheämpi ruiskasvusto oli. Jos tämäntapainen ilmiö on yleisempi, se saattaa selittää muidenkin syksyllä itäneiden kasvilajien suuren yksilötiheyden tiheissä syysruiskasvustoissa. 
Taulukko 16. Rikkaruohojen yksilö- tai versomäärä $/ \mathrm{m}^{2}$ peittaamattomalla ja peitatulla siemenellä kylvetyillä lohkoilla.

Table 16. Number of weed plants or shoots $/ m^{2}$ on field's sown with seeds without seed dressing and with seed dressing.

\begin{tabular}{ccc}
\hline & Peittaamaton & Peitattu \\
No seed dressing & Seed dressing \\
\hline
\end{tabular}

Peittaamattomalla tiheimmässä kasvava

Highest density on field without seed dressing

Agrostis spp.

Chamaenerion angustifolium

Peitatulla tiheimmässä kasvavat

Highest density on field with seed dressing

Capsella bursa-pastoris

Cerastium caespitosum

Lapsana communis

Matricaria spp.

Myosotis arvensis

Ranunculus acris s, lat.

$R$. auricomus coll.

Taraxacum spp.

Poa trivialis

Tiheyksissä ei todettu eroja

No differences in densities

Agropyron repens

Chenopodium album s. lat.

Erysimum cheiranthoides

Galeopsis spp.

Gnaphalium uliginosum

Poa pratensis s. lat.

Polygonum aviculare s. lat.

P. lapathifolium

Ranunculus repens

Stellaria media

Viola arvensis
26.7

1.1

5.6

0.2

1.9

2.8

2.4

5.4

6.9

6.2

0.8

0.2

2.7

1.8

3.3

5.7

10.9

8.4

0.8

0.3

2.9

5.4
12.5

28.7

9.0

49.2

10.0

13.7

7.3

8.6

11.1

10.4

29.5
13.2

26.1

10.3

33.4

5.2

6.8

6.6

2.1

7.9

10.6

27.0

\subsection{Aluejako}

Suomen syysviljapelloista on tehty aikaisemmin rikkakasvifloristinen aluejako (M. RaAtikainen et al. 1979). Aluejaossa olivat kuitenkin mukana sekä syysvehnä- että syysruispellot. Tämän pelkästään syysrukiista kerätyn aineiston perusteella tehtiin myös aluejako sovellettua Sørensenin yhtäläisyysverrannetta käyttäen (M. RAATIKAINEN et al. 1979). Tuloksena oli aluejako, jossa Lounais-Suomen alueeseen kuuluivat tutkimusalueet 1-4, 7-10, ja 13-16 ja Väli-Suomen alueeseen tutkimusalueet 5, 6, 11, 12, 17 ja 18 (ks. taulukko 1). Aluejako oli siis samanlainen kuin kaikista syysviljoistakin tehty aluejako. Selvimpänä erona oli se, että tässä jaossa Juupajoen-Oriveden alue eli alue 10 sijoittui vielä selvemmin Lounais-Suomen vyöhykkeeseen kuin edellisessä jaossa. Rikkakasvien yleisyysprosentit ja yksilötiheydet eri alueilla käyvät ilmi taulukosta 3 . 
Taulukko 17. Rikkaruohojen yksilö- tai versomäärä/m² lannoittamattomilla ja keväällä typpilannoituksen saaneilla lohkoilla.

Table 17. Number of weed plants or shoots $/^{2}$ on fields without and with nitrogen fertilization in spring.

$\begin{array}{cc}\text { Lannoittamaton } & \text { Lannoitettu } \\ \text { Not fertilized } & \text { Fertilized }\end{array}$

Lannoittamattomilla tiheimmässä

Highest density on fields without fertilization

Agropyron repens

13.1

Myosotis arvensis

7.7

7.2

Taraxacum spp.

3.3

2.5

Trifolium repens

3.9

1.8

Lannoitetuilla tiheimmässä

Highest density on fields with fertilization

Chenopodium album s. lat.

16.5

31.8

Fumaria officinalis

0.2

0.5

Galeopsis bifida

0.9

1.4

Polygonum convolvulus

2.8

4.6

Poa trivialis

1.2

4.8

Tiheyseroa ei todettu

No difference in densities

Agrostis spp.

Erysimum cheiranthoides

Galeopsis spp.

Gnaphalium uliginosum

Lapsana communis

4.7

5.9

Matricaria spp.

9.0

9.0

Poa pratensis s. lat.

Polygonum aviculare s. lat.

P. lapathifolium

10.3

3.0

Ranunculus repens

11.3

8.6

Stellaria media

9.0

11.2

Viola arvensis

31.1

26.9 
Taulukko 18. Rikkaruohojen yksilö- tai versotiheys $/ \mathrm{m}^{2}$ kesäkuun eri aikoina.

Table 18. Weed plant or shoot densities $/ m^{2}$ on different dates in June.

\begin{tabular}{cccc}
\multicolumn{3}{c}{ Kesäkuun päivät - Dates in June } \\
\hline $1 .-5$. & $6 .-7$. & $8 .-9$. & $10 .-18$.
\end{tabular}

Tilastollinen ero todettu

Statistical difference

Equisetum arvense

$\begin{array}{lllr}2.3 & 1.4 & 0.7 & 2.7 \\ 0.7 & 0.4 & 0.2 & 0.2 \\ 2.6 & 1.6 & 0.3 & 1.2 \\ 0.1 & 0.4 & 0.4 & 0.6 \\ 2.2 & 2.0 & 3.2 & 12.4 \\ 0.2 & 0.5 & 0.4 & 0.6 \\ 1.2 & 1.4 & 2.4 & 4.9 \\ 2.9 & 5.9 & 4.7 & 16.4 \\ 1.2 & 2.8 & 2.6 & 14.3 \\ 0.1 & 0.4 & 0.4 & 1.5\end{array}$

Cirsium arvense

Thlaspi arvense

Rumex acetosa s. lat.

Spergula arvensis

Fumaria officinalis

Trifolium repens

Gnaphalium uliginosum

Polygonum lapathifolium

0.4

1.5

Ei tilastollista eroa

No statistical difference

Agropyron repens

13.6

8.1

21.2

12.3

Agrostis spp.

7.0

18.8

13.5

Chenopodium album s. lat.

19.8

30.6

26.1

27.2

Erysimum cheiranthoides

9.5

11.4

33.6

8.3

Galeopsis spp.

32.6

Lapsana communis

38.9

9.1

53.4

6.0

4.7

39.2

5.9

Myosotis arvensis

6.3

7.1

5.8

7.1

Matricaria spp.

11.8

8.4

9.8

9.2

Poa pratensis s. lat.

4.9

5.8

5.7

15.5

Polygonum aviculare s. lat.

4.9

7.8

17.8

9.4

Ranunculus repens

5.1

4.2

4.9

13.6

Rumex acetosella s. lat.

0.7

3.6

19.4

13.6

Stellaria media

7.1

10.9

2.7

3.8

37.4

23.0

11.5

13.1

Viola arvensis 
Taulukko 19. Syysrukiin peittävyyden vaikutus rikkaruohojen yksilö- tai versotiheyteen $/ \mathrm{m}^{2}$. Table 19. Influence of percentage of area covered by winter rye on the density of weed plants or shoots $/ m^{2}$,

Syysrukiin peittävyys \%

Percentage of area covered by winter rye

\begin{tabular}{llll}
\hline $1-20$ & $21-40$ & $41-60$ & $61-100$
\end{tabular}

Tilastollinen ero todettu

Statistical difference

Polygonum lapathifolium

Stellaria graminea

Galeopsis spp.

Sonchus arvensis

Viola arvensis

Poa trivialis

Agrostis spp.

Galeopsis speciosa

Galium vaillantii

Stellaria media

$\begin{array}{rrrr}11.1 & 6.4 & 3.8 & 1.1 \\ 0.3 & 0.2 & 0.1 & 0.1 \\ 54.2 & 43.8 & 46.7 & 22.5 \\ 0.2 & 0.5 & 0.2 & 0.1 \\ 32.9 & 33.4 & 23.1 & 24.7 \\ 0.1 & 7.5 & 3.5 & 2.9 \\ 9.7 & 18.5 & 20.6 & 11.5 \\ 0.2 & 3.0 & 1.5 & 10.2 \\ 0.0 & 0.3 & 0.2 & 0.5 \\ 8.9 & 10.8 & 9.0 & 12.9\end{array}$

Ei tilastollista eroa

No statistical difference

Agropyron repens

$\begin{array}{llll}8.6 & 19.5 & 10.6 & 11.7\end{array}$

Chenopodium album s. lat.

27.4

31.0

21.4

29.7

Erysimum cheiranthoides

11.4

8.2

11.7

Gnaphalium uliginosum

Lapsana communis

Matricaria spp.

6.8

Myosotis arvensis

$\begin{array}{ll}8.7 & 10.1\end{array}$

Poa pratensis s. lat.

\section{Tiivistelmä}

Tutkimus tehtiin v. $1972-1974$ koko Suomesta otannalla poimituilla 325 syysruislohkolla, joiden pinta-ala oli $0.7 \%$ maan ruisalasta.

Ruista viljeltiin keskimääräistä suuremmilla tiloilla. Sitä viljeltiin suositusten mukaan etenkin kevyehköillä kivennäismailla ja keskinkertaisen kosteilla tai poutivilla mailla. Leikkuupuintia ja herbisidejä rukiin viljelylohkoilla ei ollut käytetty kovin usein. Esikasvina oli Lounais-Suomessa tavallisimmin kevätvilja tai ruis ja Väli-Suomessa nurmi tai kevätvilja. Peruslannoitukseksi annettiin karjanlantaa $30 \%: 1 l e$ ja väkilannoitteita $92 \%: 1 l e$ ruislohkoista. Lajikkeet olivat yleensä alueelle suositeltuja. Kylvösiemenestä peitattiin vain $48 \%$, ja kylvösiementä käytettiin usein liikaa, mikä aiheutti tiheitä ja lakoontuvia kasvustoja. Kylvökausi oli liian pitkä, mistä seurasi yksittäisillä tiloilla huomattavia sadonmenetyksiä. Kahukärpästä ei torjuttu kemiallisesti eikä talvituhosieniäkään orasasteella juuri koskaan. Typpeä käytettiin kevätlannoituksessa yleensä suositellut määrät, mutta eräissä tapauksissa liikaa, kun samalla muu nykyaikainen viljelytekniikka laiminlyötiin. 
Ruislohkoista käsiteltiin herbisideillä $25 \%$ ja korrenvahvisteella $15 \%$. Ruisalasta oli vain $0.9 \%$ nurmen suojaviljana.

Ruislohkoilta löydettiin 176 putkilokasvilajia. Lajimäärä oli suurin ItäSuomessa. Kaikkien lajien yleisyysprosentit määritettiin. Yleisimmät lajit olivat syysyksivuotisista Viola arvensis, Stellaria media, Matricaria spp., Myosotis arvensis ja Lapsana communis, kevätyksivuotisista Chenopodium album, Galeopsis spp., Erysimum cheiranthoides, Polygonum aviculare ja $P$. convolvulus ja monivuotisista Ranunculus repens, Agrostis spp., Cerastium caespitosum, Phleum pratense ja Agropyron repens.

Lohkoilla oli keskimäärin 303 rikkaruohoa $/ \mathrm{m}^{2}$. Tiheys oli pienin LounaisSuomessa. Kaikkien lajien yksilömäärä tai versomäärä $/ \mathrm{m}^{2}$ määritettiin. Tiheimmässä kasvoivat syysyksivuotisista Viola arvensis, Stellaria media, Matricaria spp., Myosotis arvensis ja Lapsana communis, kevätyksivuotisista Galeopsis spp.,Chenopodium album ja Erysimum cheiranthoides ja monivuotisista Agrostis spp., Agropyron repens, Poa pratensis ja Ranunculus repens.

Tilakoko, lohkon ikä peltona, maalaji, maaperän kosteus, leikkuupuintikertojen määrä, herbisidiruiskutusten määrä, esikasvi, kylvöaika, peittaus, kasvukauden vaihe, viljan peittävyys ja viljelyalue vaikuttivat joko suoranaisesti rikkaruohojen tiheyteen tai olivat tiheyden indikaattoreita. Rukiinviljelyalue jakaantui rikkakasvien perusteella kahteen alueeseen.

\section{Kiitokset.}

Esitämme parhaat kiitokset työtä monipuolisesti tukeneelle prof. Jaakko Mukulalle, kenttätyön tekijöille, kokoomatyössä avustaneelle LuK Päivi Haliselle, tietokonekäsittelyssä avustaneelle maist. Liisa Mattilalle, käsikirjoitukseen korjauksia tehneille agr. Paavo Simojoelle ja maist. Raija Lehtiselle. Kiitos myös maatalous-metsätieteelliselle toimikunnalle käsittely- ja kirjoitusvaiheessa saadusta apurahasta.

\section{KIRJALLISUUSLUETTELO}

AAmisepp, A., Stecko, V. \& ÅBerg, E. 1967. Ogräsfröspridning vid bindarskörd och skördetröskning. Summary: Distribution of weed seeds at binder harvest and combining. Lantbr.högsk. Medd. 8: 1-31.

Anov. 1974. Salaojitusyhdistys 1973. 55. toimintavuosi. 27 p. Toijala.

- 1975. Viljele oikein ruista. Koetoim. ja Käyt. 32: 14-15.

Antrinen, O. 1958. Syysrukiin kylvöaikakokeet Pohjois-Pohjanmaan koeasemalla. Summary: Sowing time trials with winter rye at North Pohjanmaa Experimental Station. Maatal. ja Koetoim. 12: 154-158.

Brummer, V., KesävaAra, H. \& Alitalo, O. 1971. Rikkakasvien levinneisyystutkimus 1969-70. SvT-Tutkimusseloste. Sokerijuurikkaanviljelyn Tutkimuskeskuksen Tied. 1: $1-20$.

Draper, N. R. \& Smith, H. 1966. Applied regression analysis. 407 p. New York-LondonSydney.

ERvıö, L.-R. 1973. Jauhosavikka (Chenopodium album L) kilpailijana puhtaassa kasvustossa ja viljassa. Summary: Chenopodium album L. as a competitor in pure stand and in cereals. 25 p. Helsinki.

- 1976. Rikkakasvien torjunta syysrukiista keväällä. Maatalouden Tutkimuskeskus. Kasvinviljelylaitoksen Tiedote 2: $1-6$.

Essen, M. von 1913. Tutkimuksia rehukasviviljelyksen alalta. 282 p. Helsinki. 
Grotenfelt, G. 1899. Det primitiva jordbrukets metoder i Finland under den historiska tiden. 443 p. Helsingfors.

- 1921-1922. Suomalainen peltokasviviljelys II. 517 p. Helsinki.

- \& PUнакка, V. 1914. Selostus heinänurmiemme kylvöä, hoitoa ja ikää koskevista tiedusteluista v. 1910. Suomen maanviljelys-taloudellinen koelaitos. Vuosikertomus 1911-1912: $116-152$.

НаккоцA, H. 1966. Syysviljojen kylvöaika Lounais-Suomessa. Koetoim. ja Käyt. 23: 32 .

HARVEY, W. R. 1966. Least-squares analysis of data with unequal subclass numbers. ARS 20-8. Agric. Res. Service, U.S. Dep. of Agric. 157 p.

HerNonen, R. 1975. Jordarterna och deras brukningsegenskaper. Lantbr.högsk. Medd. B 23: $1-42$.

HonkavaAra, T. 1958. Syysviljojen kylvöaikakokeet Etelä-Pohjanmaan koeasemalla. Referat: Saatzeitversuche mit Wintergetreide in der Versuchstation für Süd-Pohjanmaa. Maatal. ja Koetoim. 12: 177-187.

Hänninen, P. \& Jamalainen, E. A. 1968. Syysviljojen talvehtiminen Keski-Suomessa. Summary: Overwintering of winter cereals in Central Finland. Ann. Agric. Fenn. 7: $194-218$.

Jalas, J. \& JuUsela, T. 1959. Unkrautstudien und Bodenuntersuchungen auf den Grundwasserstauparzellen des wasserwirtschaftlichen Versuchsfeldes Maasoja in Vihti, Südfinnland. Ann. Bot. Soc. Vanamo 30, 5:1-61.

Jamalainen, E. A. 1958. Experiments on the use of some chloronitrobenzene and organic mercury compounds for the control of low-temperature parasitic fungi on winter cereals J. Scient. Agric. Soc. Finl. 30: 251-263.

- 1962. Syysviljojen peittauskokeet Suomessa. Summary: Trials on seed treatment of winter cereals in Finland. Ann. Agric. Fenn. 1: 175-191.

- 1964. Control of low-temperature parasitic fungi in winter cereals by fungicidal treatment of stands. Ann. Agric. Fenn. 3: 1-54.

JoKELA, M. 1971. Rikkakasvien siementen esiintyminen timotein ja puna-apilan kauppasiemenessä. Summary: Occurrence of weed seeds in Finnish timothy and red clover seed. Maatil.hall. Tied. 370: $41-47$.

KARES, M. 1973. Rukiin viljely- ja korjuutekniikka. Koetoim. ja Käyt. 30: 14-15.

KAUHANEN, V. 1975. Iisalmen seudun viljapeltojen rikkakasvillisuudesta ja sitä säätelevistä tekijöistä. Savon Luonto 7:45-50.

Konsala, J. 1971. Syysruislajikkeet Etelä-Suomessa. Tikkurilan koetuloksia v. 1966-70. Koetoim. ja Käyt. 28: 25, 28.

Korsmo, E. 1935. Undersøkelser over innhold av ugressfrø i melle, agner, høimo, husdyrgjødsel og kulturjord. 1900-1025. Summary: Investigations respecting the content of weedseeds in grain-screenings, chaft, hay-barn sweepings, farmyard manure and cultivated soil. 1900-1925. 139 p. Oslo.

KöPPÄ, P. (toim.) 1975. Kasvinviljelyoppi 3. 202 p. Helsinki.

- 1976. Kasvinviljelyoppi 2. 287 p. Helsinki.

KöYLIJĀRVI, J. 1971. Ruislajikkeet Lounais-Suomen oloissa. Koetoim. ja Käyt. 28: 27.

- 1972. Syysviljojen typpi syys-, talvi, vai kevätlevityksenä. Koetoim. ja Käyt. 29: 38.

- 1974. Syysviljojen kylvö Lounais-Suomen oloissa. Koetoim. ja Käyt. 31: 25.

- 1975. Syysviljojen lannoitus, kylvö ja lajikkeet. Maatalouden Tutkimuskeskus. Lounais-Suomen Koeaseman Tiedote 3:1-29.

LAMpinen, R. 1971. Kasvinviljely. Pelto-Pirkan Päiväntieto 1972: 76-81.

LıNNomāKI, H. 1958. Syysrukiin kylvőaikakokeet Hämeen koeasemalla. Summary: Sowing time trials with winter rye at Häme Experimental Station. Maatal. ja Koetoim. 12: $147-153$.

Luostarinen, H. 1969. PCNB ja CCC syysrukiin viljelyssä. Koetoim. ja Käyt. 26: 3-4.

- 1971. Syysrukiin ja ohran klormekvattikokeiden tuloksia. Koetoim. ja Käyt. 28: 2-3.

- \& LAasonen, M. 1973. Syysrukiin typpilannoitus ja laontorjunta. Koetoim. ja Käyt. 30: 36 .

Majaniemi, I. (toim.) 1960. Maanviljelysoppi 1. 300 p. Porvoo-Helsinki.

- 1962. Maanviljelysoppi 2.462 p. Porvoo-Helsinki. 
MarJanen, H. 1975. Syysviljojen talvehtimisesta paikalliskokeiden koetulosten valossa. Maatalouden Tutkimuskeskus. Paikalliskoetoimiston Tiedote 1:1-31.

MarkKulA, M. 1973. Sales of pesticides in Finland 1972. Kem. Teoll. 30: 360-361.

- 1974. Sales of pesticides in Finland in 1973. Kemia-Kemi 1:625-628.

- \& Tirttanen, K. 1975. Sales of pesticides in Finland in 1974. Kemia-Kemi 2: $377-$ 378.

Mukula, J., Raatikainen, M., Lallukka, R. \& Raatikainen, T. 1969. Composition of weed flora in spring cereals in Finland. Ann. Agric. Fenn. 8: 59-110.

- Rantanen, O., Lallukka, U. \& Pohjonen, V. 1976. Rukiin viljelyvarmuus Suomessa 1950-1975. Maatalouden Tutkimuskeskus. Kasvinviljelylaitoksen Tiedote 5:1-77.

- \& Ruuttunen, E. 1969. Chemical weed control in Finland in 1887-1965. Ann. Agric. Fenn. 8, suppl. 1: 1-45.

- \& Teittinen, P. 1967. Uusia kokemuksia kemiallisesta laontorjunnasta. Koetoim. ja Käyt. 24:13, 16.

PaAtela, J. 1953. Peltonurmien perustamistavoista Suomessa. Summary: On cultural methods used at establishing rotation leys in Finland. Acta Agr. Fenn. 79, 1:1-81.

PEssı, Y. 1969. Typpilannoitteiden syyslevityksestä. Leipä Leveämmäksi 17, 4:29-31.

- 1970. Väkilannoitteet ja niiden käyttő peltoviljelyssä. 214 p. Porvoo-Helsinki.

Petzoldt, K. 1959. Wirkung des Mähdruschverfahrens auf die Verunkrautung. Z. Acker- u. Pfl.bau 109: 49-78.

Poijärvi, I. \& Wecksell, J. A. (toim.) 1943. Maamiehen käsikirja. 628 p. Helsinki.

Poranen, E. 1972. Peltojen rikkakasvillisuudesta Kuopiossa ja Siilinjärvellä. Zusammenfassung: Ưber Unkrautvegetation auf Äckerin in Kuopio und Siilinjärvi. Savonia 1: $1-32$.

PäLıкKö, E. 1960. Uudisviljely. Maanviljelyoppi 1: 145-162.

RaAtikainen, M. \& RAatikainen, T. 1964. Kevätviljapeltojen ja niiden pientareiden kasveista Laihialla. Summary: Plant species growing on spring cereal fields and their edges at Laihia, Finland. J. Scient. Agric. Soc. Finl. 36: 135-160.

- \& RaAtikainen, T. 1972. Weed colonization of cultivated fields in Finland. Ann. Agric. Fenn. 11: 100-110.

- \& RAatikainen, T. 1975. Heinänurmien sato, kasvilajikoostumus ja sen muutokset. Summary: Yield, composition and dynamics of flora in grassland for hay in Finland. Ann. Acric. Fenn., 14:57-191.

- , RaAtikainen, T. \& Mukula, J. 1979. Weed species, frequencies and densities in winter cereals in Finland. Ann. Agric. Fenn. 17: 115-142.

- , Raatikainen, T. \& Tinnilä, A. 1971. Rikkakasvit ja niiden torjunta. Kasvinsuoj.seur. Julk. 46: 1-108.

Sauli, J. O. (toim.) 1929. Maa ja metsä 1. Kasvituotanto 2: $361-798$. Porvoo.

- 1943. Peltokasvinviljelys. Maamiehen käsikirja. p. 103-241. Helsinki.

Schubert, R., Hilbig, G. \& Mahn, E.-G. (toim.) 1975. Probleme der Agrogeobotanik. Wiss. Beitr. Martin-Luther-Univ. 1973/11 (P2): 1-213 + 1-16.

Sıмојокı, P. 1976. Rukiin kylvöaika. Referat: Rågens såningstid. Kehittyvä Maatalous 28: $29-31$.

Srmonen, S. (toim.) 1944. Maatalouden Pikku Jättiläinen. 2. painos. 1212 p. Porvoo-Helsinki.

SoININEN, A. M. 1975. Vanha maataloutemme. Maatalous ja maatalousväestö Suomessa perinnäisen maatalouden loppukaudella 1720-luvulta 1870-luvulle. Abstract: Old traditional agriculture in Finland in the 18th and 19th centuries. J. Scient. Agric. Soc. Finl. 46, suppl.: $1-459$.

Sørensen, T. 1948. A method of establishing groups of equal amplitude in plant sociology based on similarity of species content. K. Danske Vidensk. Selsk. Biol. Skr. 5, 4:1-34.

Sunila, J. E. et al. (toim.) 1915. Pienviljelijän käsikirja. 2. painos. 436 p. Porvoo.

TIItTANEN, K. 1959. Kahukärpäsen viljakasveissa aiheuttamat tuhot Suomessa vuosina 1948-1958. Referat: Schäden durch die Fritfliege (Oscinella frit L., Dipt.) bei Getreide in Finnland in den Jahren 1948-1958. Publ. Finn. State Agric. Res. Board. 178: 110-125.

WALle, O. 1929. Nurmikasvit. SAUli, J. O. (toim.) Maa ja Metsä 1. Kasvintuotanto II: 747-798. 
VALLE, O. 1958. Kylvöajan merkityksestä syysrukiin ja syysvehnän viljelyssä Etelä-Suomessa. Summary: The influence of sowing time on the cultivation of winter rye and winter wheat in South Finland. Maatal. ja Koetoim. 12: 159-176.

- 1962. Viljakasvien viljely. Maanviljelysoppi 2: $91-144$. Porvoo-Helsinki.

VARIS, E. 1976. Rukiin typpilannoitus ja korrenvahvistajan käyttö. Summary: Nitrogen application to rye and the use of CCC in connection with it. Hankkijan Kasvinjalostuslaitos. Siemenjulkaisu 1975: $183-186$.

Vuorela, T. 1975. Suomalainen kansankulttuuri. 776 p. Porvoo-Helsinki.

YLLö, L. 1967. CCC:n vaikutus rukiin kasvuun. Koetoim. ja Käyt. 24: 33.

- 1969. Syysrukiin ja syysvehnän kylvöaikakokeet Kasvinviljelylaitoksella 1958 (1927) -1967. Summary: Sowing date trials with winter rye and winter wheat at the Department of Plant Husbandry, 1958 (1927)-1967. Ann. Agric. Fenn. 8: 184-192.

Käsikirjoitus saapunut 6.6.1979. 